\title{
METODE PEMBUKTIAN TERBALIK PADA TINDAK PIDANA KORUPSI
}

\author{
Wawan Prasetyo \\ PT. Bank Tabungan Neagara (Persero)Tbk, Kantor Cabang Karawang Jalan Kertabumi \\ No 29 A-D Kab. Karawang.413। | notonegorowawan@yahoo.com
}

\begin{abstract}
This study is analyzes the Reversed Evidence Method in Restoring the State Financial Loss Caused by Corruption that are introduced in anti-corruption law in Indonesia. The research shows that the reversed method, as referred to article $12 \mathrm{~B}, 37,37 \mathrm{~A}$ and 38 B of Undang-Undang No. 3I Year 1999 Juncto Undang-Undang No. 20 Year 2001, is a new methodologicalsystem on Criminal Law Procedure and Islamic Criminal Law Procedure in Indonesia. Through this kind of evidence method, the public prosecutor will use the result of the verification which had been carried out in reverse by the defendant as novum. If the defendant successfully proves his possession is not from corruption, there is no reason for the prosecutor to demand that the property is seized for the state. Conversely, if the defendant unsuccessfully proves, then it can be used as a novum to demand that the property is seized for the state. So, if the public prosecutor uses this method in uncovering the crime of corruption, it might be a very effective method in term of restoring the state's financial loss.
\end{abstract}

Keywords: Reversed evidence, corruption, Islamic criminal procedure

Abstrak: Penelitian ini merupakan hasil penelitian metode pembuktian terbalik dalam mengembalikan kerugian keuangan negara pada tindak pidana korupsi menurut UU No. 31 Tahun 1999 juncto UU No. 20 Tahun 200 I tentang pemberantasan tindak pidana korupsi perspektif hukum acara pidana Islam. Hasil penelitian menunjukkan bahwa metode pembuktian terbalik sebagaimana dimaksud dalam pasal $12 \mathrm{~B}$, 37, 37 A dan 38 B UU No. 3 I tahun 1999 jo UU No. 20 tahun 200I, merupakan metode baru dalam sistem pembuktian pada Hukum Acara Pidaba Indonesia dan Hukum Acara Pidana Islam. Melalui metode pembuktian semacam ini, jaksa penuntut umum akan menggunakan hasil dari pembuktian secara terbalik yang dilakukan oleh 
terdakwa sebagai novum. Apabila terdakwa berhasil membuktian harta bendanya bukan berasal dari perbuatan korupsi maka tidak ada alasan bagi jaksa untuk menuntut bahwa harta benda tersebut dirampas untuk negara. Sebaliknya apabila terdakwa tidak berhasil membuktikan, maka hal tersebut dapat dijadikan novum untuk menuntut agar harta tersebut dirampas untuk negara. Apabila metode ini diterapkan oleh penuntut umum dalam mengungkap kejahatan korupsi, adalah metode yang sangat efektif dalam kaitannya mengembalikan kerugian keuangan negara yang timbul dari kejahatan korupsi.

Kata Kunci: Pembuktian terbalik, korupsi, Hukum Acara Pidana Islam

\section{Pendahuluan}

Korupsi merupakan bagian yang tak terpisahkan dalam sejarah perkembangan manusia dan termasuk jenis kejahatan yang tertua serta merupakan salah satu penyakit masyarakat, sama dengan jenis kejahatan lain seperti pencurian yang sudah ada sejak manusia ada di atas bumi ini. ${ }^{1}$ Namun yang menjadi catatan adalah meningkatnya korupsi seiring dengan kemajuan dan kemakmuran teknologi. Bahkan ada gejala dalam pengalaman yang memperlihatkan, semakin maju pembangunan suatu bangsa, maka semakin meningkat pula kebutuhan hidup seseorang dan mendorong orang untuk melakukan korupsi.

Demikianlah realitasnya, sehingga Raja Sihonouk dari Kamboja pernah berkata, "bahwa dia akan berusaha meningkatkan pembangunan di negaranya, walaupun dengan konsekuensi akan meningkat pula korupsi". Mungkin beliau menyadari, melihat kenyataan empiris di Indonesia yang pembangunannya sedemikian hebat sampai pertumbuhan ekonomi mencapai $7 \%$ pertahun, namun sejalan dengan itu korupsi meningkat pula yang semakin hari semakin mengawatirkan. ${ }^{2}$

' Djoko Sumaryanto, Pembalikan Beban Pembuktian Tindak Pidana Korupsi Dalam Rangka Pengembalian Kerugian Keuangan Negara, (Jakarta: Prestasi Pustaka Raya, 2009), I

2 Jur Andi Hamzah, Perbandingan Pemberantasan Korupsi di Berbagai Negara, Jakarta: Sinar Grafika, 2005), I 
Dari kaca mata Internasional, pada dasarnya korupsi merupakan salah satu kejahatan dalam klasifikasi white collar crime 3 dan mempunyai akibat kompleksitas serta menjadi perhatian masyarakat Internasional. Ban Ki-Moon (Sekretaris Jenderal PBB) menegaskan bahwa "harta negara yang dikorupsi dapat membiayai program sosial dan insfrastruktrur publik". Menurut M. Fadjroel Rachman dalam bukunya Rekor Koruptor, seperti yang dikutip oleh Djoko Sumaryanto mengatakan" "kini yang terpenting adalah korupsi di suatu negara bukan lagi masalah negara itu sendiri, tetapi sudah menjadi masalah/kepedulian semua negara, bangsa dan negara di dunia".

Masalah korupsi sebenarnya bukanlah masalah baru di Indonesia, karena telah ada sejak era tahun 1950-an. Bahkan berbagai kalangan menilai korupsi telah menjadi bagian dari kehidupan, menjadi suatu sistem dan menyatu dengan penyelenggaraan pemerintahan negara. Penanggulangan korupsi di era tersebut banyak menemui kegagalan. ${ }^{5}$

Indonesia, menurut lembaga survey Internasional Political and Economic Risk Consultancy yang bermarkas di Hongkong merupakan salah satu negeri terkorup di Asia. Indonesia terkorup di antara 12 negara di Asia, diikuti India dan Vietnam. Thailand, Malaysia, dan Cina berada pada posisi keempat. Sementara negara yang menduduki peringkat terendah tingkat korupsinya adalah Singapura, Jepang, Hongkong, Taiwan dan Korea Selatan. Pencitraan Indonesia sebagai negara paling korup berada pada nilai 9,25 derajat, sementara India 8,9, Vietman 8,67, Singapura 0,5 dan Jepang 3,5 derajat dengan dimulai dari 0 derajat sampai 10.6

\footnotetext{
${ }^{3}$ Konsep White Collar Crime adalah kejahatan yang dilakukan oleh orang-orang yang memiliki posisi/jabatan pada corporate, sedangkan korupsi dilakukan oleh orang-orang yang berkenaan dengan jabatan dan corporate tersebut.

${ }^{4}$ Djoko Sumaryanto, Pembalikan Beban Pembuktian, I

5 Chaerudin, et all, Strategi Pencegahan dan Penegakan Hukum Tindak Pidana Korupsi, (Bandung: Refika Aditama, 2008), I

${ }^{6}$ Kwik Kian Gie, "Negara Terkorup di Asia", http://www. Kompas.com. Di akses pada tanggal 31 Agustus 2012
} 
Hasil riset yang dilakukan oleh berbagai lembaga menunjukkan bahwa tingkat korupsi di Indonesia yang mayoritas penduduknya beragama Islam ini termasuk yang paling tinggi di dunia. Terlebih berdasarkan survey yang dilakukan oleh Transparency International Indonesia bahwa Indonesia di tahun 2005 menduduki negara ke-6 terkorup di dunia, sementara pada tahun sebelumnya tercatat sebagai negara terkorup ke-5 dari 146 negara ${ }^{7}$. Koran Singapura, The Straits Times, sekali waktu pernah menjuluki Indonesia sebagai the envelope country. Mantan ketua BAPPENAS, Kwik Kian Gie, menyebut lebih dari Rp.300 triliun dana dari penggelapan pajak, kebocoran APBN, maupun penggelapan hasil sumber daya alam, menguap masuk ke kantong para koruptor. Di samping itu, korupsi yang biasanya diiringi dengan kolusi, juga membuat keputusan yang diambil oleh pejabat negara menjadi tidak optimal.

Komisi Pemberantasan Korupsi dalam siaran pers akhir tahun 2011 menyebutkan bahwa:

"Guna mencegah terjadinya korupsi pada aset atau kekayaan milik negara, KPK melakukan kegiatan penyelamatan aset/kekayaan negara semenjak 2009. Total aset/kekayaan negara yang berhasil diselamatkan dalam tahun 2011 ini sebesar Rp. 152.957.821.529.773 (seratus lima puluh dua triliun sembilan ratus lima puluh tujuh miliar delapan ratus dua puluh satu juta lima ratus dua puluh sembilan ribu tujuh ratus tujuh puluh tiga rupiah). Jumlah tersebut terdiri atas penyelamatan potensi kerugian negara akibat pengalihan hak barang milik negara (BMN) sebesar Rp532.198.228.000 (Lima ratus tiga puluh dua miliar seratus sembilan puluh delapan juta dua ratus dua puluh delapan ribu rupiah); dan penyelamatan keuangan negara dan kekayaan negara dari sektor hulu migas sebesar Rp152.425.623.301.773 (seratus lima puluh dua triliun empat ratus dua puluh lima miliar enam ratus dua puluh tiga juta tiga

${ }^{7}$ Denny Indrayana, Negara Dalam Darurat Korupsi, (Jakarta: Sinar Grafika, 2005), 3

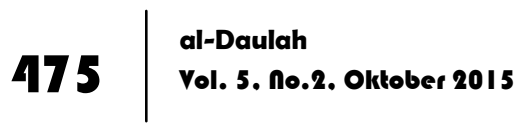


ratus satu ribu tujuh ratus tujuh puluh tiga rupiah). Jumlah kerugian keuangan negara yang berhasil diselamatkan dan masuk ke dalam Penerimaan Negara Bukan Pajak (PNBP) dari penanganan perkara tindak pidana korupsi (TPK) yang telah disetorkan ke Rekening Kas Negara/Daerah sebesar Rp.134.655.993.776 (seratus tiga puluh empat miliar enam ratus lima puluh lima juta sembilan ratus sembilan puluh tiga juta tujuh ratus tujuh puluh enam rupiah), yang antara lain berasal dari uang pengganti, uang rampasan, uang sitaan, penjualan hasil lelang TPK, dan ongkos perkara" ${ }^{\prime}$.

Jumlah nilai kerugian keuangan negara yang diselamatkan KPK di atas cukup untuk :

1. Memberikan 2 juta rumah sederhana gratis, atau

2. Membangun jalan nasional sepanjang 700 kilometer, atau

3. Mencukupi kebutuhan beras 23 juta penduduk setahun

4. Memberikan sekolah gratis kepada 64 juta anak hingga lulus $\mathrm{SD}$, atau

5. Membangun 1,2 juta unit ruang kelas Sekolah Dasar, atau

6. Membangun 1,1 juta unit ruang kelas Sekolah Menengah Pertama

Begitu dahsyatnya akibat yang ditimbulkan dari perbuatan korupsi. Tidak hanya perekonomian nasional saja yang mengalami keterpurukan, lebih dari itu memiliki imbas yang luar biasa terhadap sektor yang lain, misalnya sosial, pendidikan, hukum, keamanan, dan lain sebagainya.

Sebagai suatu kejahatan yang extra ordinary crime ${ }^{9}$, pemberantasan tindak pidana korupsi membutuhkan keseriusan dan dengan cara melakukan kerjasama Internasional. Dalam pemberantasan korupsi, keseriusan pemerintah Indonesia dapat

${ }^{8}$ www. kpk.go.id diakses pada tanggal 4 September 2012

9 Lihat Penjelasan UU No. 31 tahun 1999 tentang Pemberantasan Tindak Pidana Korupsi. Disebut Extra Ordinary Crime menunjukkan bahwa pemberantasan tindak pidana korupsi dilakukan dengan "Cara luar biasa" dan "cara yang khusus" . Yang dimaksud adalah pembalikan beban pembuktian yang dibebankan kepada terdakwa. 
terlihat dengan diterbitkannya berbagai kebijakan yang secara langsung berkaitan dengan penanggulangan tindak pidana korupsi. Indonesia adalah Negara pertama yang mencanangkan suatu peraturan khusus mengenai pemberantasan korupsi di Asia. Penguasa Perang Pusat Kepala Staf Angkatan Darat yang dijabat Jendral A.H Nasution menciptakan suatu peraturan untuk memberantas korupsi yang gejalanya sudah tampak pada tahun 1958. Peraturan Penguasa Perang Pusat Kepala Staf Angkatan Darat tanggal 16 April 1958 Nomor Prt/Peperpu/C 13/1958 dan peraturan pelaksananya diikuti oleh Penguasa Perang Pusat Kepala Staf Angkatan Laut Nomor Prt/Z.1./1/7 tanggal 17 April $1958^{10 .}$

Dari peraturan tersebut lahir Undang-Undang Nomor 24 (Prp) Tahun 1960, Undang-Undang Nomor 3 Tahun 1971, dan Undang-Undang Nomor 31 Tahun 1999 tentang Pemberantasan Tindak Pidana Korupsi, dan yang terakhir ialah Undang-Undang Nomor 20 Tahun 2001 Tentang Perubahan Atas Undang-Undang Nomor 31 Tahun 1999 tentang Pemberantasan Tindak Pidana Korupsi.

Salah satu hal yang menjadi bagian terpenting dan harus diperhatikan dalam masalah pemberantasan korupsi ialah mengembalikan asset atau keuangan negara yang telah diambil oleh koruptor tanpa hak. Karena bagaimanapun juga negara masih membutuhkan asset atau keuangan yang telah dikorup tersebut untuk melanjutkan pembangunan nasional yang sempat tersendat oleh korupsi.

Dari sejumlah pasal yang mengatur tindak pidana korupsi, hanya dua pasal yang mengatur tindak pidana korupsi (tipikor) yang merugikan keuangan negara, yaitu Pasal 2 dan 3 UU No. 31 tahun 1999 dan UU No. 20 tahun 2001 tentang Pemberantasan Tindak Pidana Korupsi. ${ }^{11}$ Walaupun hanya dua pasal, pasal ini

\footnotetext{
${ }^{10}$ Jur Andi Hamzah, Perbandingan Pemberantasan Korupsi di Berbagai Negara, 78

" UU No. 3I tahun 1999 dan UU No. 20 tahun 200I tentang Pemberantasan Tindak pidana Korupsi oleh penulis selanjutnya disebut UU Tindak Pidana Korupsi.
}

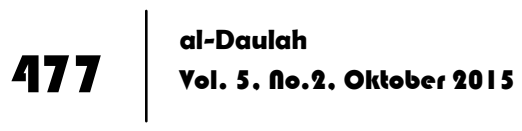


sangat favorit dipakai untuk menjerat para pelaku korupsi yang secara keseluruhan telah menimbulkan kerugian negara hingga triliunan rupiah. Hal ini tidak berarti bahwa delik Korupsi haruslah merugikan keuangan negara.

Di dalam Undang-Undang Tindak Pidana Korupsi terdapat ketentuan baru dalam hal pengembalian asset atau keuangan negara, yaitu ketentuan dengan menggunakan asas pembalikan beban pembuktian atau pembuktian terbalik.12 Pembuktian terbalik merupakan bagian dari hukum pembuktian acara pidana khusus, sehingga pembuktian terbalik tidak diatur didalam Kitab Undang-Undang Hukum Acara Pidana, namun diatur dalam Undang-Undang pemberantasan Tindak Pidana Korupsi, yaitu Undang-Undang Nomor 31 Tahun 1999 tentang Pemberantasan Tindak Pidana Korupsi, juncto Undang-Undang Nomor 20 Tahun 2001 Tentang Perubahan Atas Undang-Undang Nomor 31 Tahun 1999 tentang Pemberantasan Tindak Pidana Korupsi. Ketentuan khusus mengenai pembuktian terbalik dalam perkara korupsi terdapat dalam pasal 12 B ayat (1) huruf a dan b, pasal 37, pasal 37 A, pasal 38 B Undang-Undang Nomor 20 Tahun 2001 Tentang Perubahan Atas Undang-Undang Nomor 31 Tahun 1999 tentang Pemberantasan Tindak Pidana Korupsi ${ }^{13}$.

Lebih lanjut dalam pasal $12 \mathrm{~B}$ ayat 1 huruf a dan b UndangUndang Nomor 20 Tahun 2001 menyebutkan :

"Setiap gratifikasi kepada pegawai negeri atau penyelenggara Negara dianggap pemberian suap, apabila berhubungan dengan jabatannya dan yang berlawanan dengan kewajiban atau tugasnya, dengan ketentuan sebagai berikut:

a. Yang nilainya $\mathrm{Rp} 10.000 .000,00$ (sepuluh juta rupiah) atau lebih, pembuktian bahwa gratifikasi tersebut bukan merupakan suap dilakukan oleh penerima gratifikasi;

\footnotetext{
2 Djoko Sumaryanto, Pembalikan Beban Pembuktian, I I

13 Adami Chazawi, Hukum Pembuktian Tindak Pidana Korupsi UU No. 31 tahun 1999 yang diubah dengan UU No. 20 tahun 200 I, ( Malang: Bayumedia Publishing, 201 I), 74
} 
b. Yang nilainya kurang dari Rp 10.000.000,00 (sepuluh juta rupiah), pembuktian bahwa gratifikasi tersebut suap dilakukan oleh penuntut umum." 14

Pada pasal 37 dan 37 A Undang-Undang Nomor 20 Tahun 2001 Tentang Perubahan Atas Undang-Undang Nomor 31 Tahun 1999 dijelaskan;

\section{Pasal 37}

(1) Terdakwa mempunyai hak untuk membuktikan bahwa ia tidak melakukan tindak pidana korupsi.

(2) Dalam hal terdakwa dapat membuktikan bahwa ia tidak melakukan tindak pidana korupsi, maka pembuktian tersebut dipergunakan oleh pengadilan sebagai dasar untuk menyatakan bahwa dakwaan tidak terbukti.

\section{Pasal 37 A}

(1) Terdakwa wajib memberikan keterangan tentang seluruh harta bendanya dan harta benda istri atau suami, anak, dan harta benda setiap orang atau korporasi yang diduga mempunyai hubungan dengan perkara yang didakwakan.

(2) Dalam hal terdakwa tidak dapat membuktikan tentang kekayaan yang tidak seimbang dengan penghasilannya atau sumber penambahan kekayaannya, maka keterangan sebagaimana dimaksud dalam ayat (1) digunakan untuk memperkuat alat bukti yang sudah ada bahwa terdakwa telah melakukan tindak pidana korupsi.

(3) Ketentuan sebagaimana dimaksud dalam ayat (1) dan ayat (2) merupakan tindak pidana atau perkara pokok sebagaimana dimaksud dalam Pasal 2, Pasal 3, Pasal 4, Pasal 13, Pasal 14, Pasal 15, dan Pasal 16 Undang-undang Nomor 31 Tahun 1999 tentang Pemberantasan Tindak Pidana Korupsi dan Pasal 5 sampai dengan Pasal 12 Undang-undang ini, sehingga penuntut umum tetap berkewajiban untuk membuktikan dakwaannya.

${ }^{14}$ Pasal 12 B Undang-Undang Nomor 20 Tahun 200 I Tentang Perubahan Atas Undang-Undang Nomor 31 Tahun 1999 tentang Pemberantasan Tindak Pidana Korupsi. 
Sedangkan sandaran terakhir selain ketiga pasal di atas tentang pembuktian terbalik ialah pada pasal 38 B, yang menyebutkan :

(1) Setiap orang yang didakwa melakukan salah satu tindak pidana korupsi sebagaimana dimaksud dalam Pasal 2, Pasal 3, Pasal 4, Pasal 13, Pasal 14, Pasal 15, dan Pasal 16 Undangundang Nomor 31 Tahun 1999 tentang Pemberantasan Tindak Pidana Korupsi dan Pasal 5 sampai dengan Pasal 12 Undangundang ini, wajib membuktikan sebaliknya terhadap harta benda miliknya yang belum didakwakan, tetapi juga diduga berasal dari tindak pidana korupsi.

(2) Dalam hal terdakwa tidak dapat membuktikan bahwa harta benda sebagaimana dimaksud dalam ayat (1) diperoleh bukan karena tindak pidana korupsi, harta benda tersebut dianggap diperoleh juga dari tindak pidana korupsi dan hakim berwenang memutuskan seluruh atau sebagian harta benda tersebut dirampas untuk negara."

Dengan menerapkan asas pembuktian terbalik sebagaimana dimaksud dalam pasal 12 B ayat (1) huruf a, dari penjelasanpenjelasan pasal 37 Undang-Undang Nomor 31 Tahun 1999 dan pasal 37 Undang-Undang Nomor 20 Tahun 2001, dapatlah diketahui bahwa kedua undang-undang tersebut menerapkan pembuktian terbalik yang bersifat terbatas atau berimbang dengan unsur-unsur sebagai berikut: ${ }^{15}$

1. Terdakwa tindak pidana korupsi mempunyai hak untuk membuktikan bahwa ia tidak melakukan tindak pidana korupsi, sebagaimana dimaksud dalam pasal 37 ayat 1 Undang-Undang No.31 Tahun 1999 sebagaimana telah diubah dengan pasal 37 ayat (1) Undang-UNdang No. 20 Tahun 2001.

15 Ermansjah Djaja, Memberantas Korupsi Bersama KPK (Komisi Pemberantasan Korupsi) KajianNormatif UU No. 31 tahun 1999 junto UU No. 20 tahun 200I versi UU no 30 Tahun 2002, (Jakarta: Sinar Grafika, 2008), 128 
2. Terdakwa tindak pidana korupsi mempunyai kewajiban untuk memberikan keterangan tentang seluruh harta bendanya dan harta benda isteri atau suami, anak dan harta benda setiap orang atau korporasi yang diduga mempunyai hubungan dengan perkara yang bersangkutan, sebagaimana dimaksud pasal 37 ayat (3) Undang-Undang No. 31 Tahun 1999 sebagaimana telah diubah dengan pasal 37 ayat (1) Undang-Undang No. 20 Tahun 2001.

3. Penuntut umum Komisi Pemberantas Korupsi tetap mempunyai kewajiban untuk membuktikan dakwaanya, sebagaimana dimaksud pasal 37 ayat (5) Undang-Undang No. 31 Tahun 1999 sebagaimana telah diubah dengan pasal 37 ayat (3) Undang-UNdang No. 20 Tahun 2001.

Tidak hanya dalam tata hukum Indonesia, pembuktian juga memegang peranan penting dalam Hukum Acara Pidana Islam. Tujuannya pun sama, yaitu untuk menegakkan keadilan, dan menyatakan siapa yang seharusnya bertanggung jawab. Pembuktian tentang benar tidaknya terdakwa melakukan perbuatan yang didakwakan, merupakan bagian yang terpenting dalam Hukum Acara Pidana Islam. Dalam hal ini hak asasi manusia dipertaruhkan. Bagaimana akibatnya jika seseorang yang didakwa dinyatakan terbukti melakukan perbuatan yang didakwakan berdasarkan alat bukti yang ada disertai keyakinan hakim, padahal tidak benar. Untuk itulah Hukum Acara Pidana Islam bertujuan mencari kebenaran materiil.

Dalam Islam korupsi dipandang sebagai kejahatan yang sangat meresahkan rakyat, terlebih yang melakukan korupsi adalah para penyelenggara pemerintahan. Islam menetapkan sanksi yang berat terhadap pelaku tindak pidana korupsi.

Firman Allah dalam Surat al-Baqarah ayat 188 yang artinya "Dan janganlah sebahagian kamu memakan harta sebahagian yang lain di antara kamu dengan jalan yang bathil dan (janganlah) kamu membawa (urusan) harta itu kepada hakim, supaya kamu dapat memakan 
sebahagian daripada harta benda orang lain itu dengan (jalan berbuat) dosa, padahal kamu Mengetahui"16.

Korupsi tidak dianggap sebagai pencurian biasa. Dilihat dari segi sarana, fasilitas, dan dampak negatif dari tindak pidana korupsi, sebagaimana disinggung di atas. Tindak pidana korupsi adalah jenis pencurian yang luar biasa. Oleh karena itu, hukumannya juga luar biasa. Ia juga termasuk pidana " $t a^{\prime} z i r^{\prime}$, yaitu Pemerintah bisa menetapkan dasar perundang-undangan, jenis-jenis hukuman yang sesuai dengan jenis-jenis pidana korupsi yang dilakukan, dan sesuai dengan tuntutan kemaslahatan rakyat dan negara, namun harus lebih berat daripada hukuman pencurian biasa dalam obyek kejahatan yang sama nilainya. Sama dengan jarimah lainya (kejahatan), yang mana seseorang dinyatakan bersalah melakukan tindak pidana korupsi oleh hakim harus melalui mekanisme pembuktian. Seperti yang disinggung di atas pembuktian adalah aspek kunci dalam sebuah perkara dapat diputus.

Produk pengadilan yang berupa penetapan dan keputusan, dikeluarkan oleh pengadilan melaui suatu proses pemeriksaan perkara yang didalamnya terdapat suatu tahapan yang disebut pembuktian. Ibnu Qayyim ${ }^{17}$ menyebutkan "bukti, secara global, merupakan sebutan segala sesuatu yang menjelaskan dan mengungkapkan kebenaran,terutama dua orang saksi, atau empat orang saksi yang tidak terhalang haknya untuk menjadi saksi atas nama dua orang saksi". Al Qur'an menyebut pembuktian tidak hanya semata-mata dalam arti dua orang saksi. Akan tetapi, juga dalam arti keterangan, dalil dan alasan baik secara sendiri-sendiri maupun komulasi.

\footnotetext{
16 Departemen Agama RI, Al-Qur'an dan Terjemahannya, (Bandung: Penerbit Diponegoro,200I), 23

${ }^{17}$ Ibnu Qayyim al-Jauziyah, at-T\{uru///>q al-Hukmiyyat fi as-Siya > sati as-Syar'yati, terjemah, Adnan Qahar dan Anshoruddin, Hukum Acara Peradilan Islam, (Yogyakarta: Pustaka Pelajar, 2006), 15
} 
Apa yang disampaikan oleh Ibnu Qayyim di atas sesuai dengan firman Allah dalam Surat al-Hujurat ayat 6 yang artinya: "Hai orang-orang yang beriman, jika datang kepadamu orang fasik membawa suatu berita, Maka periksalah dengan teliti agar kamu tidak menimpakan suatu musibah kepada suatu kaum tanpa mengetahui keadaannya yang menyebabkan kamu menyesal atas perbuatanmu itu."18

Rasulullah SAW menjelaskan masalah pembuktian ini sebagai berikut, sebagaimana Sabda Nabi :

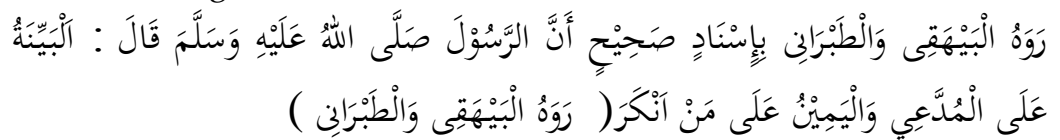

"Diriwayatkan al-Bayhaqy dan at-Tabrani dengan sanad yang sohih, bahwasanya Rasulullah SAW bersabda, bukti itu (wajib) atas penggugat dan sumpah itu (wajib) atas pihak yang menolak (pengakuan)".

Menurut Ibnu Qayyim ${ }^{19}$ hadis tersebut dimaksudkan, bahwa untuk mendapatkan hukum yang sesuai dengan petitum gugatannya, seorang penggugat harus mengemukakan bukti-bukti yang membenarkan dalil-dalil gugatannya. Dan dua orang saksi adalah termasuk alat bukti. Memang kadang bukti-bukti lain selain dua orang saksi lebih memiliki nilai kekuatan pembuktian daripada saksi. Hal itu karena adanya petunjuk keadaan yang seolah-olah berbicara atas dirinya sendiri yang membuktikan kebenaran penggugat. Bukti adalah lebih memiliki nilai kekuatan pembuktian daripada keterangan saksi. Dalil, keterangan, alasan, gejala, indikasi dan ciri-ciri, semuanya mempunyai makna yang berdekatan.

Pandangan Ibnu Qayyim ini seolah menekankan bahwa penggugat harus membuktikan kebenaran gugataanya di depan majelis hakim, sehingga didapati terbentuknya keyakinan hakim atas apa yang digugatkan kepada penggugat. Dengan demikian si

\footnotetext{
${ }^{18}$ Departemen Agama RI, Al-Qur'an dan Terjemahannya, 412

${ }^{19}$ Ibnu Qayyim al-Jauziyah, Hukum Acara Peradilan Islam, I 5
} 
penggugat hanya dibebankan sumpah terhadap apa yang di gugatkan kepadanya.

Imam Ahmad, sebagaiman dikutip oleh Ibnu Qayim 20 memberikan penjelasan ;

"bahwa sumpah dibebankan kepada pihak mana yang tidak jauh dari kebenaran dan dengan sumpahnya itu maka pihaknya dipandang sebagai in confesto. Kemudian ,jika pihak tergugat diketahui berada di pihak yang kuat, maka dengan asas praduga tak bersalah sumpah ditempatkan sebagai haknya. Ketentuan ini juga berlaku terhadap para tergugat sebagai pihak penerima amanat, seperti penitipan barang, penyewa, orang yang diberi kuasa sebagai wakil, dan penerima wasiat. Maka, mereka diberi hak untuk mengangkat sumpah, kemudian keteranganya dibawah sumpah dianggap in confesto."

Dengan demikian, pembuktian dalam Hukum Acara Pidana Islam menekankan kepada pihak penggugat sebagai pihak yang harus membuktikan gugataanya. Sehingga perlu dibahas perihal sistem pembuktian terbalik yang memegang peranan terpenting dalam memberantas tindak pidana korupsi baik dalam kaitannya menemukan siapa tersangkanya atau sebagai jalan dalam rangka mengembalikan kerugian keuangan negara.

\section{Pembuktian dalam Tindak Pidana Korupsi}

\section{Sistem Pembuktian dalam Hukum Acara Pidana Indonesia}

Tujuan dari pembuktian adalah untuk mencari dan menerapkan kebenaran-kebenaran yang sesungguhnya, bukan semata-mata mencari kesalahan-kesalahan seseorang. Walaupun pada praktiknya kebenaran absolut tidak akan pernah dicapai. Tetapi dengan penelitian serta dengan ketekunan dengan mempergunakan bukti yang ada, paling tidak akan mencapai suatu kebenaran yang dipercaya. 
Dalam rangka menerapkan pembuktian dalam hukum pidana Indonesia dikenal adanya beberapa teori hukum pembuktian. Menurut Andi Hamzah, secara teoritik dikenal 4 (empat) teori tentang pembuktian, yaitu berupa ${ }^{21}$ :

a. Teori pembuktian berdasarkan undang-undang secara positif

Teori ini berpendapat bahwa sistem pembuktian hanya berdasarkan peraturan peraturan perundang-undangan saja. Artinya jika telah terbukti suatu perbuatan sesuai dengan alat-alat bukti yang disebut oleh undang-undang, maka keyakinan hakim tidak diperlukan sama sekali. Dengan kata lain, hakim tidak memiliki kewenangan untuk menilai alat bukti sebagai penunjang fakta hukum yang ada dalam persidangan. Teori ini disebut juga dengan pembuktian formal.

Menurut Simons seperti yang dikutip oleh Andi Hamzah ${ }^{22}$ "sistem atau teori ini berusaha untuk menyingkirkan semua pertimbangan subyektif hakim, dan mengikat hakim secara ketat menurut peraturan-peraturan pembuktian yang keras.

b. Teori pembuktian berdasarkan keyakinan hakim melulu

Teori pembuktian ini memberikan kesempatan seutuhnya kepada hakim dalam menilai fakta-fakta hukum dalam persidangan dan mengenyampingkan peraturan perundangundangan. Kesempatan hakim yang terlalu besar dalam menilai fakta hukum membuat lemahnya sistem pengawasan terhadap para hakim dalam memeriksa perkara. Sistem pembuktian yang demikian pernah dianut di Indonesia. Seperti pendapatnya Andi Hamzah" 23 "pengadilan adat dan swapraja pun memakai sistem keyakinan hakim melulu selaras dengan kenyataan bahwa pengadilan-pengadilan tersebut dipimpin oleh hakim-hakim yang bukan ahli (berpendidikan hukum). Sebagai contoh keterangan medium atau dukun di pergunakan hakim dalam memutus perkara.

${ }^{21}$ Jur Andi Hamzah, Hukum Acara Pidana Indonesia, (Jakarta: Sinar Grafika, 2008), 249-254

22 |bid., 25|

${ }^{23}$ lbid., 252 
c. Teori pembuktian berdasarkan keyakinan hakim atas alasan yang logis

Menurut teori ini, hakim adapat memutus perkara berdasarkan keyakinannya, keyakinan yang didasarkan pada dasar-dasar pembuktian disertai dengan suatu kesimpulan yang berlandaskan pada peraturan pembuktian tertentu. Dalam perkembangannya, teori ini terpecah menjadi dua aliran, pertama; pembuktian berdasrkan keyakinan hakim atas alasan yang logis, seperti yang disebutkan diatas. Kedua; pembuktian berdasarkan undang-undang secara negatif.

d. Teori pembuktian berdasarkan undang-undang secara negatif Teori ini merupakan pecahan dari teori pembuktian berdasarkan keyakinan hakim atas alasan yang logis. Seperti yang diuraikan diatas bahwa, teori ini membatasi hakim dalam memtus perkara untuk tidak mengenyampingkan aturan pembuktian dalam undang-undang. Maksudnya adalah membatasi hakim dalam tingkat subyektifitasnya, agar putusan hakim benar-benar objektif.

Menurut Martiman Prodjohamidjojo24 Perkataan "negatif" dipakai oleh karena adanya alat-alat bukti yang disebut juga dalam undang-undang. Hal ini belum berarti hakim mesti menjatuhkan pidana. Hal ini tergantung pada keyakinan hakim atas kebenaran.

Dari empat teori pembuktian yang diuraikan di atas, yang dianut oleh hukum acara pidana Indonesia baik secara teori maupun praktik peradilan terdapat 2 (dua) teori yang dianut. Berikut kami paparkan penjelasannya :

a. Menganut teori pembuktian berdasarkan undang-undang secara negatif

Sebelum KUHAP disahkan pada tanggal 31 Desember 1981 dalam peraturan perundang-undangan Indonesia melalui UU No 8 Tahun 1981 tentang Kitab Undang-Undang Hukum Acara

24 Martiman Prodjohamidjojo, Penerapan Pembuktian Terbalik Dalam Delik Korupsi (UU No. 20 Tahun 2001), (Bandung: Mandar Maju, 2009), 83 
Pidana, aparat penegak hukum dalam beracara pada peradilan pidana berpedoman pada Herzine Indonesisch Reglement (HIR). Dalam hal aturan pembuktian diatur dalam pasal 294 ayat (1) HIR menyebutkan bahwa: "Tidak akan dijatuhkan hukuman kepada seorangpun jika hakim tidak mendapat keyakinan dengan upaya bukti menurut undang-undang bahwa benar telah terjadi perbuatan pidana dan bahwa pesakitan salah melakukan perbuatan itu".

Kemudian sesudah KUHAP ditetapkan menjadi pedoman pokok dalam beracara pada peradilan pidana melalui UU No. 31 Tahun 1981, bunyi pasal 294 ayat (1) tersebut selanjutnya diserap dalam UU No. 31 Tahun 1981. Dan diletakkan dalam pasal 183 KUHAP, yang menyatakan bahwa: "Hakim tidak boleh menjatuhkan pidana kepada seorang kecuali apabila dengan sekurang-kurangnya dua alat bukti yang sah ia memperoleh keyakinan bahwa suatu tindak pidana benar-benar terjadi dan bahwa terdakwalah yang bersalah melakukannya".

Rumusan pasal 183 KUHAP dapat dinilai lebih sempurna, karena telah menentukan batas yang lebih tegas bagi hakim dalam usaha membuktikan kesalahan terdakwa untuk menjatuhkan pidana. Lebih tegas karena ditentukan batas minimum pembuktian yakni harus menggunakan sekurangkurangnya dua alat bukti yang sah dari yang disebutkan undangundang. Sedangkan dalam pasal 294 ayat (2) HIR syarat setidaktidaknya dengan alat bukti sebagaimana disebutkan dalam pasakl 183 KUHAP tidak disebutkan secara tegas.

Berangkat dari titik tolak pasal 183 KUHAP ini, kriteria menentukan bersalah tidaknya seorang terdakwa, hakim haruslah memperhatikan aspek-aspek berikut ini. Pertama, kesalahan terdakwa haruslah terbukti dengan sekurang-kurangnya dua alat bukti yang sah. Kedua, bahwa atas dua alat bukti yang sah tersebut hakim memperoleh keyakinan bahwa tindak pidana memang benar-benar terjadi dan terdakwalah pelakunya. 
b. Menganut teori pembuktian berdasarkan undang-undang secara positif

Aspek "keyakinan hakim" yang termuat dalam pasal 183 KUHAP dalam praktiknya tidak diterapkan secara limitatif. Apabila dalam suatu putusan hakim pada amar putusanya tidak mencantumkan rumusan keyakinanya yang berupa "secara sah dan meyakinkan", kelalaian tersebut tidak menyebabkan putusan tersebut batal demi hukum.

Semestinya, apabila kita konsekuen menggunakan teori berdasarkan undang-undang secara negatif, jika tidak mencantumkan kata "secara sah dan meyakinkan", maka putusan tersebut batal demi hukum. Pada praktiknya dalam tingkat banding atau kasasi hanya akan diperbaiki dengan menambahkan kata-kata "secara sah dan meyakinkan" dalam amar putusanya. ${ }^{25}$

\section{Sistem Pembebanan Pembuktian}

Sebagaimana telah dijelaskan diatas, bahwa secara teoritis Ilmu Pengetahuan Hukum Acara Pidana asasnya mengenal 4 (empat) teori pembuktian. Konsekuensi logis teori hukum pembuktian tersebut berkorelasi dengan eksistensi terhadap asas beban pembuktian. Menurut Lilik Mulyadi, dikaji dari Ilmu Pengetahuan Hukum Acara Pidana dikenal 3 (tiga) teori tentang pembebanan pembuktian ${ }^{26}$ :

a. Beban pembuktian pada penuntut umum

Menurut teori ini Penuntut Umum haruslah mempersiapkan alat-alat bukti umumdan barang bukti secara akurat, sebab jika tidak demikian akan susah dalam meyakinkan hakim tentang kesalahan terdakwa. Pada realitanya, Teori ini berlandaskan pada ketentuan pasal 66 KUHAP yang menyebutkan bahwa:

25 Sebagai contoh atas praktik tersebut dapat dilihat dalam putusan Mahkamah Agung RI No 664 K/ Pid/ 1986 tanggal 29 November 1990.

26 Lilik Mulyadi, Asas Pembalikan Beban Pembuktian Terhadap Tindak Pidana Korupsi Dalam Sistem Hukum Pidana Indonesia Pasca Konvensi Perserikatan Bangsa-Bangsa Anti Korupsi 2003, (Bandung: Alumni, 2007), 10 I 
"tersangka atau terdakwa tidak dibebani kewajiban pembuktian". Dengan demikian, tersangka atau terdakwa memiliki hak untuk tidak membuktikan atau menyangkal apa yang dituntut penuntut umum.

b. Beban pembuktian pada terdakwa

Dalam konteks ini, terdakwa berperan aktif menyatakan bahwa dirinya bukan sebagai pelaku tindak pidana. Oleh karena itu terdakwalah didepan sidang pengadilan yang akan menyiapkan segala beban pembuktian dan bila tidak dapat membuktikan, terdakwa dinyatakan bersalah melakukan tindak pidana. Pada dasarnya teori pembuktian jenis ini dinamakan dengan teori pembalikan beban pembuktian. Teori ini digunakan pada tindak pidana tetentu yang menurut penuntut umum sangant sulit dibuktikan oleh penuntut umum. Misalnya pada pembuktian tindak pidana korupsi yang merugikan keuangan negara, yang mana untuk membuktikan harta kekayaan terdakwa yang diduga berasal dari hasil korupsi sangatlah sulit.

c. Beban pembuktian berimbang

Teori ini mengajarkan bahwa, baik penuntut umum maupun tertdakwa atau penasihat hukumnya saling membuktikan dipersidangan. Lazimnya penuntut umum akan membuktikan kesalahan terdakwa. Sedangkan sebaliknya terdakwa beserta penasihat hukumnya akan membuktikan sebaliknya bahwa terdakwa tidak terbukti secara sah dan meyakinkan bersalah melakukan tindak pidana yang didakwakan.

\section{Metode Pembalikan Beban Pembuktian dalam Tindak Pidana Korupsi di Indonesia}

Delik korupsi adalah sebagaimana delik pada umumnya dilakukan dengan berbagai macam modus operandi penyimpangan keuangan negara. Sehingga banyak perkaraperkara korupsi lolos dari "jaringan" pembuktian sistem KUHAP. Karena itu pembentuk UU Tindak Pidana Korupsi membuat formulasi baru tentang pembuktian tindak pidana korupsi.

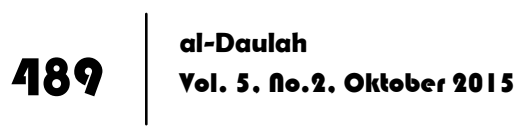


Dalam UU Tindak Pidana Korupsi diterapkan 2 (dua) sistem pembuktian sekaligus, yakni sistem UU Tindak Pidana Korupsi sekaligus sistem KUHAP. Kedua sistem tersebut menerapkan hukum pembuktian dilakukan dengan cara menerapkan pembuktian terbalik yang bersifat terbatas dan berimbang dan dengan menggunakan sistem pembuktian negatif menurut undang-undang 27 .

Dalam penjelasan atas UU No. 31 Tahun 1999, disebutkan pembuktian terbalik yang bersifat terbatas dan berimbang, yakni terdakwa mempunyai hak untuk membuktikan bahwa ia tidak melakukan tindak pidana korupsi dan wajib memberikan keterangan tentang seluruh harta bendanya, harta benda isterinya atau suami, anak, dan harta benda setiap orang atau korporasi yang diduga mempunyai hubungan dengan perkara yang bersangkutan dan penuntut umum tetap berkewajiban untuk membuktikan dakwaanya.

Gambaran sistem pembuktian terbalik dalam hukum pembuktian pidana korupsi, dapat kita jumpai dalam norma pasal 12 B ayat 1 'huruf (a) dan (b), pasal 37, pasal 37 A dan pasal 38 B UU Tindak Pidana Korupsi.

Pasal 12 B ayat 1 huruf (a) dan (b)

(1) Setiap gratifikasi kepada pegawai negeri atau penyelenggara negara dianggap pemberian suap, apabila berhubungan dengan jabatannya dan yang berlawanan dengan kewajiban atau tugasnya, dengan ketentuan sebagai berikut:

a. yang nilainya $\operatorname{Rp} 10.000 .000,00$ (sepuluh juta rupiah) atau lebih, pembuktian bahwa gratifikasi tersebut bukan merupakan suap dilakukan oleh penerima gratifikasi;

b. yang nilainya kurang dari Rp 10.000.000,00 (sepuluh juta rupiah), pembuktian bahwa gratifikasi tersebut suap dilakukan oleh penuntut umum. 


\section{Pasal 37}

1) Terdakwa mempunyai hak untuk membuktikan bahwa ia tidak melakukan tindak pidana korupsi.

2) Dalam hal terdakwa dapat membuktikan bahwa ia tidak melakukan tindak pidana korupsi, maka pembuktian tersebut dipergunakan oleh pengadilan sebagai dasar untuk menyatakan bahwa dakwaan tidak terbukti.

\section{Pasal 37 A}

1) Terdakwa wajib memberikan keterangan tentang seluruh harta bendanya dan harta benda istri atau suami, anak, dan harta benda setiap orang atau korporasi yang diduga mempunyai hubungan dengan perkara yang didakwakan.

2) Dalam hal terdakwa tidak dapat membuktikan tentang kekayaan yang tidak seimbang dengan penghasilannya atau sumber penambahan kekayaannya, maka keterangan sebagaimana dimaksud dalam ayat (1) digunakan untuk memperkuat alat bukti yang sudah ada bahwa terdakwa telah melakukan tindak pidana korupsi.

3) Ketentuan sebagaimana dimaksud dalam ayat (1) dan ayat (2) merupakan tindak pidana atau perkara pokok sebagaimana dimaksud dalam Pasal 2, Pasal 3, Pasal 4, Pasal 13, Pasal 14, Pasal 15, dan Pasal 16 Undang-undang Nomor 31 Tahun 1999 tentang Pemberantasan Tindak Pidana Korupsi dan Pasal 5 sampai dengan Pasal 12 Undang-undang ini, sehingga penuntut umum tetap berkewajiban untuk membuktikan dakwaannya.

\section{Pasal 38 B}

1) Setiap orang yang didakwa melakukan salah satu tindak pidana korupsi sebagaimana dimaksud dalam Pasal 2, Pasal 3, Pasal 4, Pasal 13, Pasal 14, Pasal 15, dan Pasal 16 Undangundang Nomor 31 Tahun 1999 tentang Pemberantasan Tindak Pidana Korupsi dan Pasal 5 sampai dengan Pasal 12 Undangundang ini, wajib membuktikan sebaliknya terhadap harta 
benda miliknya yang belum didakwakan, tetapi juga diduga berasal dari tindak pidana korupsi.

2) Dalam hal terdakwa tidak dapat membuktikan bahwa harta benda sebagaimana dimaksud dalam ayat (1) diperoleh bukan karena tindak pidana korupsi, harta benda tersebut dianggap diperoleh juga dari tindak pidana korupsi dan hakim berwenang memutuskan seluruh atau sebagian harta benda tersebut dirampas untuk negara.

3) Tuntutan perampasan harta benda sebagaimana dimaksud dalam ayat (2) diajukan oleh penuntut umum pada saat membacakan tuntutannya pada perkara pokok.

4) Pembuktian bahwa harta benda sebagaimana dimaksud dalam ayat (1) bukan berasal dari tindak pidana korupsi diajukan oleh terdakwa pada saat membacakan pembelaannya dalam perkara pokok dan dapat diulangi pada memori banding dan memori kasasi.

5) Hakim wajib membuka persidangan yang khusus untuk memeriksa pembuktian yang diajukan terdakwa sebagaimana dimaksud dalam ayat (4).

6) Apabila terdakwa dibebaskan atau dinyatakan lepas dari segala tuntutan hukum dari perkara pokok, maka tuntutan perampasan harta benda sebagaimana dimaksud dalam ayat (1) dan ayat (2) harus ditolak oleh hakim.

Subtansi pembuktian yang ada dalam ketentuan pasal tersebut mengacu pada objek yang harus di buktikan pada tindak pidana yang didakwakan oleh penuntut umum sebagaimana yang dirumuskan dalam surat dakwaannya, rincianya adalah sebagai berikut:

a. Pasal 37 merupakan dasar hukum sistem pembuktian terbalik dalam hukum acara pidana korupsi

b. Pasal 12 B ayat (1) huruf a dan pasal 38 B merupakan ketentuan mengenai tindak pidana korupsi (objeknya) yang 
beban pembuktianta menggunakan sistem pembuktian terbalik.

Dengan demikian, tindak pidana yang didakwakan merupakan aspek pokok yang harus dibuktikan oleh jaksa penuntut umum maupun terdakwa atau penasihat hukumnya. Tegasnya dalam tindak pidana korupsi ada unsur-unsur delik yang harus dibuktikan secara bersamaan. Unsur delik yang berupa perbuatan dan unsur yang melekat pada perbuatan, objek pembuktian dan diri pelaku adalah unsur yang harus dibuktikan, untuk menentukan apakah terbukti atau tidaknya delik yang didakwakan kepada terdakwa.

Pasal 37 ayat (1) yang mewajibkan terdakwa untuk memberikan keterangan tentrang seluruh harta bendanya yang diduga ada hubunganya dengan tindak pidana yang didakwakan. Ketentuan tersebut mengandung makna bahwa :

a. Harta benda terdakwa dapat didakwakan dalam surat dakwaan, disamping mendakwakan tindak pidana korupsi

b. Terdakwa dibebani kewajiban untuk membuktikan bahwa harta benda tersebut adalah harta benda yang halal.

Misalnya, terdakwa didakwa oleh jaksa penuntut umum melakukan tindak pidana korupsi dengan bentuk dakwaan secara berlapis. Yaitu dalam dakwaan primer melanggar pasal 2 ayat (1) sub b jo pasal 18 ayat 1 huruf a, b, ayat (2), (3) UU No 31 tahun 1999 jo UU No 20 tahun 2001, jo pasal 55 ayat 1 ke 1 jo pasal 64 ayat I KUHP. Kemudian subsider melanggar pasal 3 UU No 31 tahun 1999 jo UU No 20 tahun 2001 jo pasal 55 ayat 1 ke 1 jo pasal 64 ayat I KUHP. Atas dakwaan tersebut jaksa penuntut umum akan membuktikan dakwaan tersebut dari mulai dakwaan primer. Apabila dakwaan primer telah terbukti maka dakwaan subside tidak perlu dibuktikan lagi. Akan tetapi sebaliknya, apabila dakwaan primer tidak terbukti maka jaksa penuntut umum akan membuktikan dakwaan subsider. 
Menurut Adami Chazawi ${ }^{28}$ sistem pembuktian terbalik hanya dapat digunakan pada :

a. Pada korupsi suap penerima gratifikasi yang nilainya 10 juta atau lebih. Pembuktian terbalik pada korupsi suap menerima gratifikasi, dimana terdakwa dibebani kewajiban untuk membuktikan tidak melakukan korupsi menerima gratifikasi, dapat disebut dengan sistem pembuktian terbalik murni. Karena objek yang wajib dibuktikan terdakwa adalah langsung pada unsur-unsur tindak pidana yang didakwakan dalam perkara pokok, yang berakibat langsung pada pembebasan atau pemidanaan terdakwa.

b. Pada harta benda terdakwa yang belum didakwakan. Kewajiban terdakwa membuktiakn sebaliknya terhadap bukan pada unsur-unsur tindak pidana yang didakwakan. Akibat hukum dari berhasi atau tidak berhasil terdakwa membuktikan harta benda terdakwa diperoleh dari korupsi atau secara halal, tidak menentukan dipidana ataukah dibebaskan terdakwa dari dakwaan melakukan korupsi dalam perkara pokok. Melainkan hanya sekedar untuk dapat menjatuhkan pidana perampasan barang dalam hal terdakwa tidak berhasil membuktikan hartanya diperoleh secara halal. Atau sebaliknya untuk tidak menjatuhkan pidana perampasan barang apabila terdakwa berhasil membuktikan harta bendanya diperoleh secara halal.

Apabila jaksa penuntut umum berhasil membuktikan kesalahan terdakwa, maka hakim akan menyatakan dakwaan telah terbukti dan terdakwa dijatuhi pidana. Akan tetapi, apabila menurut hakim terdakwa berhasil membuktikan ketidakbersalahannya, maka pembuktian tersebut akan dipergunakan hakim untuk menyatakan terdakwa tidak terbukti, sehingga terdakwa harus diputus bebas. ${ }^{29}$

\footnotetext{
${ }^{28}$ Adami Chazawi, Hukum Pembuktian Tindak Pidana Korupsi, 74-76

${ }^{29}$ Lihat ketentuan pasal 37 UU Tindak Pidana Korupsi.
} 
Pararel dengan konteks diatas, begitu pula dalam hal pembuktian terhadap harta benda milik terdakwa yang belum didakwakan yang diduga berasal dari tindak pidana korupsi. Apabila terdakwa tidak dapat membuktikan harta benda tersebut diperoleh bukan karena tindak pidana korupsi dan hakim berwenang memutus seluruh atau sebagian harta benda dirampas untuk negara. ${ }^{30}$

\section{Alat Bukti Perkara Tindak Pidana Korupsi}

Salah satu aspek pembuktian yang menentukan hakim dalam menilai seluruh rangkaian pembuktian adalah alat bukti. Alat bukti dalam Hukum Acara Pidana diatur lebih lanjut dalam KUHAP. Alat bukti adalah segala sesuatu yang ada hubunganya dengan suatu perbuatan, dimana dengan alat-alat bukti tersebut, dapat dipergunakan sebagai bahan pembuktian guna menimbulkan keyakinan hakim atas kebenaran adanya suatu tindak pidana yang telah dilakukan oleh terdakwa. ${ }^{31}$ Alat bukti dapat diajukan oleh penuntut umum maupun terdakwa dalam persidangan. Penuntut umum mengajukan alat bukti dalam persidangan bertujuan untuk membuktikan dakwaanya. Sementara terdakwa dalam mengajukan alCat bukti pada persidangan bertujuan untuk membuktikan bahwa apa yang didakwakan oleh penuntut umum adalah tidak benar.

Alat bukti menurut KUHAP berbeda dengan alat bukti menurut Standar auditing. Sejak zaman Belanda sampai dengan tahun 1981 di negara kita tentang sumber hukum Acara Pidana berlaku Herziene Inlansch Reglement (HIR) dan mulai tahun 1981 berlaku UU No. 8 tahun 1981 tentang KUHAP. Antara HIR dengan KUHAP ada perbedaan antara lain mengenai bukti menurut hukum yaitu :

\footnotetext{
${ }^{30}$ Lihat ketentuan pasal 38 ayat $2 \cup \cup$ Tindak Pidana Korupsi.

${ }^{31}$ Alfitra, Hukum Pembuktian Dalam Beracara Pidana, Perdata Dan Korupsi Di Indonesia, Jakarta: Raih Asa Sukses, 20I I), 23
} 


\begin{tabular}{|l|l|}
\hline \multicolumn{1}{|c|}{ HIR } & \multicolumn{1}{c|}{ KUHAP } \\
\hline Pasal 295 & Pasal 184: \\
berbagai upaya bukti & Alat bukti yang sah ialah: \\
adalah: & - keterangan saksi \\
- kesaksian- kesaksian & - keterangan ahli \\
- surat-surat & - surat \\
- pengakuan & - petunjuk \\
- isyarat & - keterangan terdakwa \\
\hline
\end{tabular}

Berikut ini akan kami uraikan penjelasan tentang alat bukti menurut pasal 184 KUHAP :

1. Keterangan saksi

Keterangan saksi adalah salah satu alat bukti dalam perkara pidana yang berupa keterangan dari saksi mengenai suatu peristiwa pidana yang ia dengar sendiri, Ia lihat sendiri dan ia alami sendiri dengan menyebut alasan dan pengetahuannya itu ${ }^{32}$. Sedangkan saksi sendiri adalah orang yang dapat memberikan keterangan guna kepentingan penyidikan, penuntutan dan peradilan tentang suatu perkara pidana yang ia dengar sendiri, ia Iihat sendiri dan ia alami sendiri. ${ }^{33}$ Pada umumnya semua orang dapat menjadi saksi. Namun ada beberapa orang yang tidak diperbolehkan untuk menajdi saksi, sebagaimana yang tercantum dalam ketentuan pasal 186 KUHAP :

a. Keluarga sedarah atau semenda dalam garis lurus ke atas atau ke bawah sarnpai derajat ketiga dari terdakwa atau yang bersama-sama sebagai terdakwa.

b. Saudara dan terdakwa atau yang bérsama-sama sebagal terdakwa, saudara ibu atau saudara bapak, juga mereka yang mempunyai hubungan karena perkawinan dari anakanak saudara terdakwa sampal derajat ketiga

c. Suami atau isteri terdakwa meskipun sudah bercerai atau yang bersama-sama sebagai terdakwa.

\footnotetext{
32 Pasal I angka 27 KUHAP

${ }^{33}$ Pasal I angka 26 KUHAP
} 
Pasal 160 ayat 3 KUHAP menambahkan persyaratan keterangan saksi akan dianggap sebagai keterangan saksi yang sah dipersidangan ${ }^{34}$ apabila ia sebelum memberikan keterangan diambil sumpah terlebih dahulu oleh majelis hakim ${ }^{35}$. Apabila saksi tidak berkenan untuk disumpah, maka keterangan yang diberikan di persidangan dianggap sebagai keterangan tambahan. ${ }^{36}$ Sementara itu pasal 185 ayat 2 menentukan saksi yang diajukan di persidangan oleh kedua belah pihak minimal 2 (dua) orang saksi. ${ }^{37}$

\section{Keterangan ahli}

Keterangan ahli adalah keterangan yang diberikan oleh seorang yang memiliki keahlian khusus tentang hal yang diperlukan untuk membuat terang suatu perkara pidana guna kepentingan pemeriksaan ${ }^{38}$. Sama dengan ketentuan saksi dalam memberikan keterangan di persidangan, ahli sebelum memberikan keterangan wajib untuk bersumpah didepan majelis hakim ${ }^{39}$. Apabila ahli tidak dapat hadir dalam persidangan dengan alasan yang sah menurut undang-undang, maka ahli dapat memberikan keterangannya di depan penyidik dan sebelumnya diambil sumpah oleh penyidik terlebih dahulu. Keterangan yang diberikan

${ }^{34}$ Pasal 185 ayat I KUHAP menyebutkan "Keterangan saksi sebagai alat bukti ialah apa yang saksi nyatakan di sidang pengadilan".

35 Pasal 160 ayat 3 KUHAP menyebutkan "Sebelum memberi keterangan, saksi wajib mengucapkan sumpah atau janji menurut cara agamanya masing-masing, bahwa ia akan memberikan keterangan yang sebenarnya dan tidak lain daripada yang sebenarnya".

${ }^{36}$ Pasal 185 ayat 7 KUHAP menyebutkan "Keterangan dari saksi yang tidak disumpah meskipun sesuai satu dengan yang lain tidak merupakan alat bukti namun apabila keterangan itu sesuai dengan keterangan dari saksi yang disumpah dapat dipergunakan sebagai tambahan alat bukti sah yang lain".

37 Pasal 185 ayat 2 KUHAP menyebutkan "Keterangan seorang saksi saja tidak cukup untuk membuktikan bahwa terdakwa bersalah terhadap perbuatan yang didakwakan kepadanya."

${ }^{38}$ Pasal I angka 28 KUHAP

39 Lihat ketentuan pasal 179 ayat 2 KUHAP menyebutkan "Semua ketentuan tersebut di atas untuk saksi berlaku juga bagi mereka yang memberikan keterangan ahli, dengan ketentuan bahwa mereka mengucapkan sumpah atau janji akan memberikan keterangan yang sebaikbaiknya dan yang sebenarnya menurut pengetahuan dalam bidang keahliannya"

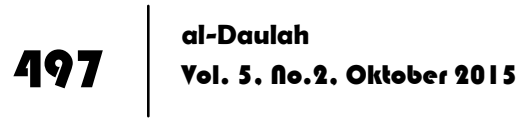


tersebut nilainya sama dengan keteran gan ahli yang diberikan didepan persidangan. ${ }^{40}$

\section{Surat}

Surat adalah segala sesuatu yang memuat tanda-tanda bacaan yang dimaksudkan untuk mencurahkan isi hati atau untuk menyampaikan buah pikiran seseorang dan dipergunakan sebagai bahan pembuktian. Dengan demikian segala sesuatu yang tidak memuat tanda-tanda bacaan, atau meskipun memuat tanda-tanda bacaan, tetapi tidak mengandung buah pikiran tidaklah termasuk dalam pengertian alat bukti surat ${ }^{41}$. Pasal 187 KUHAP memberikan penjelasan tentang macam-macam surat yang dapat dipergunakan sebagai alat bukti dalam persidangan. Adalah sebagai berikut :

Surat sebagaimana tersebut pada Pasal 184 ayat (1) huruf c, dibuat atas sumpah jabatan atau dikuatkan dengan sumpah, adalah:

a. Berita acara dan surat lain dalam bentuk resmi yang dibuat oleh pejabat umum yang berwenang atau yang dibuat di hadapannya, yang memuat keterangan tentang kejadian atau keadaan yang didengar, dilihat atau yang dialaminya sendiri, disertai dengan alasan yang jelas dan tegas tentang keterangannya itu;

b. Surat yang dibuat menurut ketentuan peraturan perundangundangan atau surat yang dibuat oleh pejabat mengenal hal yang termasuk dalam tata laksana yang menjadi tanggung jawabnya dan yang diperuntukkan bagi pembuktian sesuatu hal atau sesuatu keadaan;

c. Surat keterangan dari seorang ahli yang memuat pendapat berdasarkan keahliannya mengenai sesuatu hal atau sesuatu keadaan yang diminta secara resmi dan padanya; 
d. Surat lain yang hanya dapat berlaku jika ada hubungannya dengan isi dari alat pembuktian yang lain.

\section{Petunjuk}

Petunjuk adalah perbuatan, kejadian atau keadaan, yang karena persesuaiannya, baik antara yang satu dengan yang lain, maupun dengan tindak pidana itu sendiri, menandakan bahwa telah terjadi suatu tindak pidana dan siapa pelakunya ${ }^{42}$. Menurut Adami Chazawi ${ }^{43}$ :

"Alat bukti petunjuk adalah berupa pemikiran atau pendapat hakim yang dibentuk dari hubungan atau persesuaian alat bukti yang ada dan dipergunakan dalam sidang. Oleh karena itu pasal 188 ayat $3^{44}$ mengingatkan hakim agar dalam menilai kekuatan alat bukti petunjuk dalam setiap keadaan tertentu harus dilakukan dengan arif dan bijaksana, setelah hakim memeriksa dengan cermat dan seksama yang didasarkan hati nuraninya".

Lebih lanjut dalam pasal 1'88 ayat 2 disebutkan: Petunjuk sebagaimana dimaksud dalam ayat (1) hanya dapat diperoleh dari;

a. keterangan saksi;

b. surat;

c. keterangan terdakwa.

Apabila kita membaca dengan teliti mengenai rumusan tentang pengertian alat bukti petunjuk sebagaimana yang disebutkan dalam pasal 188 ayat 1 dan 2 maka, dapat kita peroleh kesimpulan unsur atau syarat alat bukti petunjuk adalah ${ }^{45}$ :

a. Unsur pertama adanya perbuatan, kejadian, keadaan yang bersesuaian

b. Unsur kedua, ada 2 (dua) yang dimaksud dengan persesuaian. Yaitu persesuaian antara masing-masing

\footnotetext{
${ }^{42}$ Pasal 188 ayat I KUHAP

${ }^{43}$ Adami Chazawi, Hukum Pembuktian Tindak Pidana Korupsi, 49

${ }^{44}$ Pasal 188 ayat 3 menyebutkan "Penilaian atas kekuatan pembuktian dari suatu petunjuk dalam setiap keadaan tertentu dilakukan oleh hakim dengan arif lagi bijaksana, setelah ia mengadakan pemeriksaan dengan penuh kecermatan dan kesaksamaan berdasarkan hati nuraninya".

${ }^{45}$ Adami Chazawi, Hukum Pembuktian Tindak Pidana Korupsi, 49
}

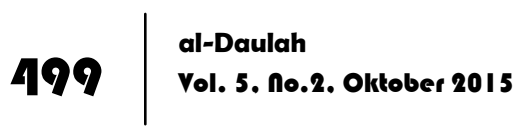


perbuatan, kejadian, dan keadaan satu dengan yang lain. Dan persesuaian antara perbuatan, kejadian, dan atau keadaan dengan tindak pidana yang didakwakan.

c. Unsur ketiga dengan adanya persesuaian yang demikian itu menandakan ada 2 (dua) hal yang sesuai dengan kejadian. Pertama menunjukkan bahwa benar telah terjadi suatu tindak pidana dan kedua menunjukkan siapa pelakunya.

d. Alat bukti petunjuk hanya dapat dibentuk melalui keterangan saksi, keterangan terdakwa dan alat bukti surat.

5. Keterangan terdakwa

Keterangan terdakwa ialah apa yang terdakwa nyatakan di sidang tentang perbuatan yang ia lakukan atau yang ia ketahui sendiri atau alami sendiri ${ }^{46}$. Tidak semua keterangan terdakwa mengandung nilai pembuktian. Dari ketentuan pasal 189 KUHAP didapatkan syarat-syarat yang harus dipenuhi agar keterangan terdakwa mengandung nilai pembuktian, ialah ${ }^{47}$ :

a. Keterangan terdakwa haruslah dinyatakan di muka sidang pengadilan

b. Isi keterangan terdakwa harus mengenai 3 (tiga) hal. Yaitu perbuatan yang dilakukan terdakwa, segala hal yang diketahuinya sendiri, kejadian yang dialaminya sendiri.

c. Nilai keterangan terdakwa hanya berlaku sebagai bukti untuk dirinya sendiri

d. Keterangan terdakwa saja tidak cukup untuk membuktikan bahwa ia bersalah melakukan perbuatan yang didakwakan kepadanya, melainkan harus disertal dengan alat bukti yang lain.

Dalam perkara tindak pidana korupsi dengan berlakunya UU No. 20 tahun 2001 tentang Perubahan atas UU No. 31 tahun 1999 tentang Pemberantasan Tindak Pidana Korupsi terdapat tambahan

${ }^{46}$ Pasal 189 ayat I KUHAP

${ }^{47}$ Adami Chazawi, Hukum Pembuktian Tindak Pidana Korupsi, 60 
untuk alat bukti petunjuk seperti yang diatur dalam pasal $26 \mathrm{~A}$, yaitu :

Alat bukti yang sah dalam bentuk petunjuk sebagaimana dimaksud dalam pasal 188 ayat (2) Undang-undang Nomor 8 tahun 1981 tentang Hukum Acara Pidana, khusus untuk tindak pidana korupsi juga diperoleh :

a. Alat bukti lain yang berupa informasi yang diucapkan, dikirim, diterima, atau disimpan secara elektronik dengan alat optik atau yang serupa dengan itu; dan

b. Dokumen, yakni setiap rekaman data atau informasi yang dapat dilihat, dibaca, dan atau didengar yang dapat dikeluarkan dengan atau tanpa bantuan suatu sarana, baik yang tertuang di atas kertas, benda fisik apa pun selain kertas, maupun yang terekam secara elektronik, yang berupa tulisan surat, gambar, peta, rancangan, foto, huruf, tanda, angka, atau perforasi yang memiliki makna.

Dengan demikian, pada tindak pidana korupsi alat bukti yang dipergunakan dalam persidangan untuk membuktikan terdakwa melakukan tindak pidana korupsi tidak hanya berpedoman pada ketentuan pasal 184 KUHAP saja, melainkan juga pada ketentuan pasal 26 A UU Tindak Pidana Korupsi. Sehingga, hakim dalam memutus perkara tindak pidana korupsi dapat mempertimbangkan macam-macam alat bukti yang ada dalam KUHAP maupun UU Tindak Pidana Korupsi yang diajukan oleh penuntut umum.

\section{Analisis Pembuktian Terbalik pada Tindak Pidana Korupsi dalam Mengembalikan Kerugian Keuangan Negara menurut UU Tindak Pidana Korupsi}

Sistem pembuktian mengacu pada ketentuan tentang standarstandar dalam hal membuktikan in casu kesalahan terdakwa melakukan tindak pidana yang di dakwakan. Seperti dalam sistem negatif menurut undang-undang yang terbatas dalam pasal 183 
KUHAP ${ }^{48}$, standar bukti itu menyatakan terbuktinya kesalahan terdakwa, ialah:

1. Berdasarkan sekurang-kurangnya dua alat bukti yang sah

2. Dari dua alat bukti tersebut hakim hakim memperoleh keyakinan terjadinya tindak pidana dan terdakwa bersalah melakukannya.

Sistem tersebut memiliki implikasi terhadap sistem pembebanan pembuktian yang mengacu pada pihak mana dibebani kewajiban membuktikan dan hal apa yang harus dibuktikan, juga mengenai standar pengukur untuk menentukan terbukti tidaknya kesalahan terdakwa.

Berpijak dari pengertian sistem pembuktian dan sistem pembebanan pembuktian yang telah diuraikan dalam bab sebelumnya, maka kekhususan dalam hukum acara pidana korupsi lebih mengacu pada sistem pembebanan pembuktian. Pada dasarnya sistem pembuktiannya sama dengan apa yang maksud pasal 183 KUHAP, khususnya bagi hakim dalam menilai alat-alat bukti. Standar yang harus diikuti untuk menyatakan terdakwa bersalah melakukan tindak pidana korupsi yang didakwakan tetap terikat pada ketentuan pasal 183 KUHAP.

Dalam hukum pembuktian tindak pidana korupsi, khususnya mengenai pembebanan pembuktian ada perbedaan dengan ketentuan KUHAP. Dalam hal-hal tertentu terdapat penyimpangan, beban pembuktian tidak mutlak ada pada penuntut umum, tetapi sebagian ada pada terdakwa atau kedua pihak yakni penuntut umum dan terdakwa atau penasihat hukumnya secara berlawanan. Inilah yang disebut dengan pembalikan beban pembuktian atau pembuktian terbalik. Disamping pembuktian terbalik untuk membuktikan tindak pidana korupsi (selain tindak pidana suap menerima gratifikasi)

\footnotetext{
${ }^{48}$ Pasal 183 KUHAP menyatakan: "Hakim tidak boleh menjatuhkan pidana kepada seorang kecuali apabila dengan sekurang-kurangnya dua alat bukti yang sah ia memperoleh keyakinan bahwa suatu tindak pidana benar-benar terjadi dan bahwa terdakwalah yang bersalah melakukannya"
} 
sistem pembebanan bisa sebagaimana yang dianut dalam KUHAP yaitu pembebanan pembuktian pada penuntut umum tetap berlaku.

Penulis berpendapat, pada sistem pembebanan pembuktian perkara korupsi, di samping memuat pihak mana (penuntut umum atau terdakwa) yang dibebani untuk membuktikan, memuat pula berbagai ketentuan, antara lain:

1. Tentang tindak pidana atau dalam hal mana berlakunya beban pembuktian pada jaksa penuntut umum atau terdakwa beserta penasihat hukumnya atau kedua-duanya. Misalnya, beban pembuktian pada jaksa penuntut umum atau terdakwa dalam hal korupsi suap menerima gratifikasi, jika nilainya Rp 10 juta atau lebih ada pada terdakwa, dan bila kurang dari Rp 10 juta beban pembuktianya ada pada jaksa penuntut umum ${ }^{49}$

2. Tentang untuk kepentingan apa beban pembuktian itu diberikan pada satu pihak. Seperti pada sisitem pembuktian terbalik, yang mana untuk membuktikan mengenai harta benda yang belum didakwakan dan di duga berkaitan dengan perbuatan korupsi, terdakwa wajib membuktikan bahwa harta benda tersebut bukan dari perbuatan korupsi. Hal ini ditujukan dengan tujuan untuk menjatuhkan atau tidak menjatuhkan pidana perampasan barang terhadap harta yang belum didakwakan ${ }^{50}$. Ini bergantung pada berhasil atau tidak berhasilnya terdakwa membuktikan asal-usul harta benda tersebut

3. Tentang tata cara membuktikan, yang mana pada hukum pembuktian tindak pidana korupsi ini disamping menggunakan cara pembebanan pembuktian kepada jaksa penuntut umum, juga menggunakan cara pembebanan pembuktian pada terdakwa. Seperti halnya cara pembuktian terbalik pada harta benda yang diduga mempunyai

\footnotetext{
${ }^{49}$ Lihat pasal I 2B UU Tindak Pidana Korupsi

${ }^{50}$ Lihat pasal 38B UU Tindak Pidana Korupsi
} 
hubungan dengan perkara korupsi yang didakwakan. Dilakukan terdakwa dengan cara membuktikan bahwa kekayaannya, isteri, suami, anak, dll yang sesuai dengan sumber penghasilan kekayaan itu ${ }^{51}$ atau harta benda yang belum didakwakan adalah bukan hasil dari perbuatan korupsi ${ }^{52}$

4. Tentang akibat hukum dari apa yang diperoleh dari hasil pembuktian pihak-pihak yang dibebani pembuktian. Seperti hakim akan menyatakan terdakwa sebagai tidak terbukti, dalam hal terdakwa dapat membuktikan tidak melakukan tindak pidana korupsi dalam sistem pembebanan pembuktian terbalik ${ }^{53}$ tentu diikuti dengan amar pembebasan (vrijspraak). Atau dalam hal terdakwa tidak dapat membuktikan bahwa harta benda yang belum didakwakan bukan hasil korupsi, akibat hukumnya harta benda tersebut dianggap sebagai hasil korupsi dan hakim akan memutus barang tersebut dirampas untuk negara ${ }^{54}$.

Tujuan pokok kegiatan pembuktian adalah untuk membuktiakn tindak pidana yang didakwakan. Sedangkan tindak pidana terdiri dari banyak unsur, maka objek pembuktiannya adalah unsur-unsur yang didakwakan. Dari argumentasi tersebut, penulis berpendapat tidak semua delik korupsi dapat diterapkan metode pembuktian terbalik. Tegasnya, pembuktian terbalik hanya dapat diterapkan terhadap kesalahan seseorang yang diduga melakukan tindak pidana korupsi menerima suap gratifikasi sebagaimana yang dimaksud dalam pasal 12 B UU Tindak Pidana Korupsi, dan terhadap harta benda terdakwa yang belum didakwakan tetapi diduga berasal dari tindak pidana korupsi sebagaimana yang dimaksud pasal 38 B. Argumentasinya adalah, walaupun kejahatan korupsi berakibat kepada

\footnotetext{
51 Lihat pasal 37 ayat (2) UU Tindak Pidana Korupsi

52 Lihat pasal 38B ayat (4) UU Tindak Pidana Korupsi

${ }^{53}$ Lihat pasal 37 ayat (2) UU Tindak Pidana Korupsi

${ }^{54}$ Lihat pasal 38 ayat (2) UU Tindak Pidana Korupsi
} 
memburuknya perekonomian negara akibat kerugian yang diderita serta sulitnya upaya mengembalikan kerugian negara, lantas tidak serta merta pembuktian dalam pidana korupsi secara elementer tidak boleh bertentangan dengan Hak Asasi Manusia, dalam hal ini asas praduga tak bersalah harus dijunjung tinggi.

Menurut penulis, sistem pembuktian terbalik yang diterapkan pada tindak pidana korupsi dipergunakan untuk membuktikan dua objek pembuktian, yaitu :

1. Objek tindak pidana korupsi suap menerima gratifikasi ${ }^{55}$

Dasar pemberlakuan sistem pembuktian terbalik pada tindak pidana korupsi adalah terdapat dalam pasal 37 UU Tindak Pidana Korupsi. Pasal 37 tersebut menyatakan bahwa "terdakwa berhak untuk membuktikan bahwa dirinya tidak melakukan tindak pidana korupsi" (ayat 1). "Dalam hal terdakwa dapat membuktikan bahwa ia tidak melakukan tindak pidana korupsi, maka pembuktian tersebut dipergunakan oleh pengadilan sebagai dasar untuk menyatakan bahwa dakwaan tidak terbukti" (ayat 2).

Jika dipandang dari aspek semata-mata hak, maka ketentuan pasal 37 ayat 1 tidaklah mempunyai arti apa-apa. Dalam sistem akusator yang dianut oleh KUHAP, hak yang demikian ditegaskan atau tidak sama saja. Hak tersebut merupakan hak dasar terdakwa yang demi hukum telah melekat pada diri terdakwa semenjak ia ditetapkan setatusnya menjadi tersangka hingga terdakwa. Ketentuan pada ayat 1 adalah bentuk penegasan belaka atas sesuatu hak terdakwa yang memang sudah ada. Justru pada norma ayat 2 nyalah yang memiliki arti penting dalam pembuktian tindak pidana korupsi.

Norma ayat 2 dalam pasal 37 tersebut menunjukkan adanya sistem pembuktian terbalik, walaupun tidak secara tuntas dijelaskan. Disebut tidak tuntas, karena walaupun pada ayat 2 dicantumkan akibat hukumnya bila terdakwa berhasil membuktikan, ialah hasil pembuktian terdakwa tersebut 
dipergunakan oleh pengadilan untuk menyatakan bahwa dakwaan tidak terbukti. Namun, tidak mencantumkan seperti hal bagaimana cara terdakwa membuktikan, adan apa setandart pengukuran hasil pembuktian terdakwa untuk menyatakan berhasil atau tidak berhasil.

Ketentuan pasal 37 ayat 2 inilah dianggap sebagai dasar hukum beban pembuktian terbalik dalam hukum acara pidana korupsi. Penerapan dari ketentuan pasal ini harus dihubungkan dengan pasal $12 \mathrm{~B}$ dan pasal $37 \mathrm{~A}$ ayat 3 . Hubunganya dengan pasal 12B ialah, bahwa sistem pembuktian terbalik pada tindak pidana korupsi berlaku pada tindak pidana korupsi suap menerima gratifikasi yang nilainya 10 juta atau lebih. Sedangkan hubunganya dengan pasal 37 A khususnya ayat 3 ialah, bahwa sistem pembuktian terbalik menurut pasal 37 berlaku terhadap pembuktian tentang sumber harta benda terdakwa dan lain sebagainya diluar perkara pokok pasal-pasal yang disebutkan dalam pasal 37A, yaitu pasal 2, 3, 4, 11, 13, 14, 15, 16 UU Tindak Pidana Korupsi. Dalam ketentuan pasal 37A ini, hanya tindak pidana suap menerima gratifikasi (pasal 12B) saja yang tidak disebutkan dalam pasal tersebut.

Ketentuan pasal 37 ayat 2 berhubungan secara terbalik dengan ketentuan mengenai seluruh harta benda terdakwa yang didakwakan dan diduga mempunyai hubungan dengan perkara korupsi yang sedang diperiksa. Apabila diteliti lebih jauh tentang macam-macam tindak pidana korupsi dalam perkara pokok yang menyangkut tentang harta benda terdakwa disebutkan secara limitatif dalam pasal 37A ayat 3, maka ternyata hanya tindak pidana korupsi suap menerima gratifikasi sebagaimana yang dimaksud pada pasal $12 \mathrm{~B}$ ayat 1 huruf (a) saja yang tidak disebutkan dalam pasal $37 \mathrm{~A}$ ayat 3 tersebut. Jadi pembuktian terbalik pada korupsi menerima gratifikasi dalam perkara pokok, dan bukan pada pembuktian mengenai harta benda yang didakwakan dalam perkara pokok sebagaimana yang dimaksud dalam pasal $37 \mathrm{~A}$. 
Selanjutnya tindak pidana suap menerima gratifikasi sebagaimana yang dirumuskan dalam pasal $12 \mathrm{~B}$ ayat (1) huruf a dan b mengandung arti :

a. Rumusan huruf a berhububgan erat dengan pasal 37, artinya ialah tentang apa yang dimaksud dengan beban pembuktian menurut norma ayat (1) huruf a in casu ada pada terdakwa itu, objek penerapannya disebutkan dalam pasal 37

b. Sistem pembuktian terbalik pasal 37 berlaku pada tindak pidana korupsi suap menerima gratifikasi yang nilainya 10 juta atau lebih

c. Sedangkan tindak pidana korupsi suap menerima gratifikasi yang nilainya kurang dari Rp 10.000.000,00 beban pembuktiannya ada pada JPU. Artinya dengan menggunakan sistem bisaa sesuai dengan ketentuan KUHAP

d. Unsur-unsur tindak pidana korupsi suap menerima gratifikasi yaitu: (1) subjek hukumnya pegawai negeri atau penyelenggara negara. (2) perbuatannya menerima gratifikasi. (4) berlawanan dengan kewajiban atau tugasnya.

2. Terhadap objek harta benda terdakwa yang belum didakwakan dan diduga diperoleh dari perbuatan tindak pidana korupsi (pasal 38 B jo 37)

Pasal 38 B sebagai dasar hukum mengenai objek harta benda yang belum didakwakan dan harus dibuktikan dengan menggunakan sistem pembebanan pembuktian terbalik. Hal yang berkaitan erat dengan sistem pembuktian terbalik terdapat pada ayat (1) ${ }^{56}$. Dari ketentuan ayat (1) ini dapat diambil kesimpulan bahwa, ada 2 (dua) hal penting, yaitu:

1. Norma ayat (1) adalah dasar hukum sistem pembuktian terbalik dalam hal pembuktian tentang harta benda

\footnotetext{
56 Pasal 38 B ayat (I) UU Tindak Pidana Korupsi menyebutkan : "setiap orang yang didakwa melakukan salah satu tindak pidana korupsi sebagaimana dimaksud dalam pasal 2, pasal 3, pasal 14, pasal 15, dan pasal 16 Undang-Undang No.3I tahun 1999 tentang Pemberantasan Tindak Pidana Korupsi dan pasal 5 sampai dengan pasal 12 Undang-Undang ini, wajib membuktikan sebaliknya terhadap harta benda miliknya yang belum didakwakan, tetapi diduga berasal dari tindak pidana korupsi.
} 
terdakwa yang belum didakwakan, tapi diduga berasal dari tindak pidana korupsi. Dengan kata lain norma ayat (1) ini menentukan tentang objek pembuktian terbalik

2. Pembuktian mengenai harta benda yang belum didakwakan sebagai bukan hasil korupsi adalah berlaku dalam hal tindak pidana yang didakwakan pada perkara pokok adalah tindak pidana korupsi pasal 2, 3, 4, 14, 15, 16, UU No. 31 tahu 1999 dan pasal 5 sampai dengan pasal 12 UU No. 20 tahun 2001.

Sedikit catatan penulis untuk hal yang kedua, ternyata hanya tindak pidana korupsi suap menerima gratifikasi (pasal 12 B) saja yang tidak disebut dalam pasal 38 ayat (1). Artinya dalam hal terdakwa didakwa melakukan tindak pidana korupsi suap menerima gratifikasi, jaksa penuntut umum tidak diperkenankan untuk menuntut pula agar terdakwa dipidana perampasan barang pada perkara pokok terhadap harta benda yang belum didakwakan sebagai hasil bukan korupsi, dalam hal terdakwa didakwa jaksa melakukan tindak pidana korupsi suap menerima gratifikasi.

Walaupun pasal 37 merupakan dasar hukum pembuktian terbalik, namun khusus mengenai objek harta benda terdakwa yang belum didakwakan (termasuk juga yang didakwakan dalam surat dakwaan) tidaklah dapat menggunakan pasal 37. Karena pasal 37 adalah khusus diperuntukkan bagi pembuktian terdakwa mengenai dakwaan tindak pidana (khususnya perbuatan suap menerima gratifikasi yang nilainya $\mathrm{Rp} 10.000 .000$ atau lebih) dan bukan dakwaan mengenai harta benda terdakwa.

Pembuktian terbalik mengenai harta benda yang belum didakwakan ini tidak menyangkut langsung dengan tindak pidana yang didakwakan dengan unsur-unsurnya dalam perkara pokok. Artinya untuk khusus membuktikan tindak pidana dalam surat dakwaan, tidak menggunakan sistem pembuktian terbalik, melainkan menggunakan sistem bisaa yang mana pembuktian mengenai tindak pidana yang didakwakan selalu berada pada 
pihak JPU. Kecuali dalam hal terdakwa di dakwa dengan pasal $12 B$ ayat (1).

Jadi walaupun terdakwa berhasil membuktikan tentang harta bendanya yang tidak didakwakan dalam surat dakwaan diperoleh dari cara yang halal dan bukan dari perbuatan korupsi, tidak dapat dijadikan dasar menarik amar putusan pembebasan melainkan sekedar menyatakan harta benda yang tidak didakwakan itu bukan hasil korupsi dan menolak tuntutan JPU untuk dirampas negara. Begitu juga sebaliknya, apabila terdakwa tidak berhasil membuktikan harta benda yang belum didakwakan berasal dari harta yang diperoleh secara halal, maka tuntutan JPU harta tersebut dirampas untuk negara harus dikabulkan oleh majelis hakim.

Prosedur cara terdakwa membuktikan harta benda yang belum didakwakan bukan dari hasil perbuatan korupsi erat kaitanya dengan objek pembuktian. Untuk objek harta benda yang tidak didakwakan dalam surat dakwaan tidak menyangkut langsung dengan unsure-unsur tindak pidana dakwaan. Artinya sisitem pembuktian terbalik untuk objek yang kedua ini bukan untuk membuktikan kesalahan terdakwa melakukan tindak pidana yang didakwakan. Bagi terdakwa ditujukan untuk menolak tuntutan jaksa penuntut umum yang menuntut agar dijatuhkannya pidana perampasan atas harta tersebut. Sebaliknya bagi jaksa ditujukan agar hakim menjatuhkan pidana perampasan barang. Padahal untuk menjatuhkan pidana apapun, syaratnya ialah harus dibuktikan dahulu tentang kesalahan terdakwa melakukan tindak pidana yang didakwakan.

Dalam hukum korupsi, untuk membuktikan unsur-unsur tindak pidana korupsi selain perbuatan gratifikasi pada pasal 12B ayat (1) tidak menggunakan sistem pembuktian terbalik, melainkan menggunakan sistem bisaa seperti pada ketentuan yang ada dalam KUHAP. Namun untuk membuktikan harta benda terdakwa yang didakwakan dan harta benda terdakwa yang 
belum didakwakan menggunakan sistem terbalik sebagaimana dimaksud dalam pasal 37A jo 38B.

Dari beberapa penjelasan yang dipaparka penulis diatas dapatlah ditarik pemahaman bahwa, pembuktian terbalik yang berkenaan dengan pengembalian kerugian keuangan negara adalah keterangan terdakwa dalam membuktikan bahwa harta bendanya bukan berasal dari tindak pidana korupsi. Keberhasilan terdakwa membuktikan tentang harta benda yang didakwakan sebagai harta yang halal, karena sumbernya sumber yang halal, tidak akan berpengaruh terhadap pembuktian penuntut umum mengenai perkara pokok, apabila penuntut umum memang berhasil membuktikan tentang unsur-unsurnya dan terbukti terdakwa bersalah melawan hukum.

Apabila terdakwa tidak berhasil membuktikan sumber penghasilan yang seimbang dengan kekayaan atau tidak terbukti sumber kekayan itu adalah sah/halal, maka penuntut umum dapat menggunakan keadaan yang demikian untuk memperkuat alat bukti yang sudah ada bahwa terdakwa bersalah melakukan tindak pidana korupsi, dan apabila terdakwa berhasil membuktikan keseimbangannya itu, berarti harta benda yang didakwakan tidak ada hubungannya dengan tindak pidana yang didakwakan dan harta benda tersebut tidak dapat dirampas untuk negara.

Pada hakikatnya, pengembalian kerugian keuangan negara akibat tindak pidana korupsi sangat penting eksistensinya. Menurut penulis, apabila dijabarkan secara sistematis maka ada beberapa argumentasi penulis sebagai justifikasi teoritis dan praktik dalam rangka eksistensi pengembalian kerugian keuangan negara akibat tindak pidana korupsi.

Justifikasi filosifis, pada aspek ini pengembalian asset tindak pidana korupsi dapat terdiri dari benda tetap maupun benda bergerak atau dapat pula berupa uang hasil dari tindak pidana korupsi. Dari dimensi ini, maka asset tersebut hakikatnya merupakan uang negara yang berasal dari masyarakat. Dengan 
menggunakan sistem pembuktian terbalik dan sisitem pemidanaan tergadap pelaku korupsi maka logikanya pelaku melakukan pengembalian asset hasil korupsi yang diharapkan berdampak langsung untuk memulihkan kerugian keuangan negara.

Justifikasi sosiologis, dikaji dari prespektif ketentuan undangundang Tindak Pidana Korupsi, maka aspirasi masyarakat untuk memberantas korupsi dan bentuk penyimpangan lainya semakin menigkat. Kenyataanya perbuatan korupsi telah menimbulkan kerugian keuangan negara yang besar sehingga berdampak pada krisis multidimensi. Untuk itu upaya pencegahan dan pemberantasan korupsi perlu semakin ditingkatkan dan diintensifkan dengan menjunjung tinggi hak asasi manusia. Asas praduga tidak bersalah dan asas kesaaman dihadapan hukum harus dijunjung yang tinggi oleh aparat penegak hukum.

Justifikasi yuridis, keberadaan ketentuan undang-undang pemberantasan korupsi yang telah ada hendaknya memberikan ruang gerak yang luas kepada aparat penegak hukum. Masyarakat dan segala lapisan untuk lebih lengkap dalam menanggulangi akibat dan dampak dari perbuatan korupsi. Oleh karena itu kebijakan legislasi yang termuat pada UU Tindak Pidana Korupsi dalam rangka asset recovery bisa dilakukan melalui jalur pidana dan perdata. Pada aspek pengembalian kerugian keuangan negara akibat perbuatan korupsi melalui prosedur pidana dapat berupa penjatuhan pidana kepada pelakunya seperti pidana denda, maupun di hukum untuk membayar uang pengganti.

\section{Analisis Pembuktian Terbalik pada Tindak Pidana Korupsi dalam Mengembalikan Kerugian Keuangan Negara menurut UU Tindak Pidana Korupsi dalam Perspektif Hukum Acara Pidana Islam}

Pembuktian terbalik pada tindak pidana korupsi sebagaimana yang dimaksud dalam pasal 12 B, 37, 37 A dan 38 B UU Tindak Pidana Korupsi dimaksudkan untuk mencari kebebaran materiil 
dan untuk mengembalikan kerugian keuangan negara yang terjadi akibat perbuatan korupsi. Pembuktian ini bisa dibilang sebagai sistem pembuktian yang baru, mengingat selama ini sistem pembebanan pembuktian hanya melulu dibebankan pada Jaksa Penuntut Umum ${ }^{57}$ yang dibebani beban untuk membuktikan. Secara ringkas pembuktian terbalik merupakan pembuktian yang membebankan pembuktian beserta alat buktinya kepada pihak tergugat atau terdakwa bersama kuasa hukumnya.

Demi mencari kebenaran materiil, maka gugatan atau dakwaan harus dibentangkan dihadapan sidang, dan ditanya satu demi satu. Dan pada dasarnya hak yang digugat atau di dakwa harus diketahui secara rasional, dan berisi tuntutan tentang sesuatu hal yang jelas, jika yang dituntut tidak jelas maka tuntutan tersebut sia-sia. Fuqaha' memberikan penjelasan tentang gugatan :

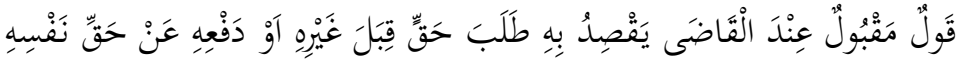

"Suatu nota gugatan yang diajukan kehadapan hakim, yang berisikan tuntutan atas hak, atau untuk mempertahankan hak tersebut".

Penulis berargumen, pembuktian terbalik merupakan wacana baru dalam Hukum Acara Pidana Islam khususnya pada mekanisme pembuktian. Hukum pembebanan pembuktian pada Acara Pidana Islam sepenuhnya menekankan pendakwa sebagai satu-satunya pihak yang dibebani pembuktian, baik dalam perkara pidana had, ta'zir maupun qisas. Sebagaimana Sabda Nabi SAW :

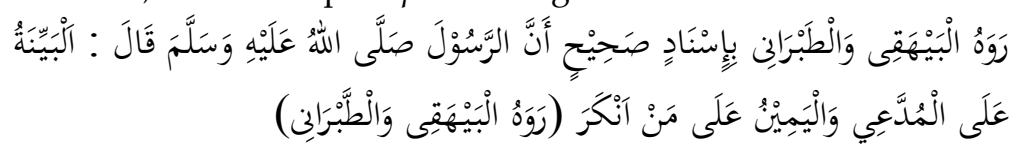

57 JPU adalah Kepanjangan dari jaksa penuntut umum, dalam Undang-Undang No. 16 tahun 2004 Tentang kejaksaan pada ketentuan umum di jelaskan : "Jaksa adalah pejabat fungsional yang diberi wewenang oleh undang-undang untuk bertindak sebagai penuntut umum dan pelaksana putusan pengadilan yang telah memperoleh kekuatan hukum tetap serta wewenang lain berdasarkan undang-undang. Penuntut Umum adalah jaksa yang diberi wewenang oleh Undang-Undang ini untuk melakukan penuntutan dan melaksanakan penetapan hakim". 
“Diriwayatkan al Bayhaqi dan al Tabrani dengan sanad yang sohih, bahwasanya Rasulullah SAW bersabda, Bukti itu (wajib) atas penggugat dan sumpah itu (wajib) atas pihak yang menolak (pengakuan)." (diriwayatkan oleh al-Bayhaqi dan at-Tabrani).

Dalam konteks pembuktian, menurut penulis, hadis tersebut dimaksudkan bahwa untuk mendapatkan putusan hukum yang sesuai dengan petitum gugatannya, seorang penggugat dalam hal ini Jaksa Penuntut Umum harus mengemukakan bukti-bukti yang membenarkan dalil-dalil gugatannya. Bukti-bukti yang dimaksud adalah tentunya berdasarkan ketentuan peraturan perundangundangan tentang macam-macam alat bukti. Dengan kata lain, tergugat atau terdakwa sama sekali tidak diberikan kewajiban untuk membuktikan secara terbalik terhadap apa yang didakwakan kepadanya, karena pada hakikatnya terdakwa tidak melakukan perbuatan seperti apa yang didakwakan kepadanya.

Dari aspek tersebut, Hukum Acara Pidana Islam berpatokan pasa asas hukum praduga tak bersalah (persumption of innocence). Asas yang mendasari bahwa seseorang yang dituduh melakukan suatu kejahatan harus dianggap tidak bersalah sebelum hakim dengan bukti-bukti yang meyakinkan menyatakan dengan tegas kesalahannya itu. Artinya terdakwa tidak boleh dianggap sebagai pelaku atas perbuatan pidana yang didakwakan, mulai semenjak terdakwa diperiksa sebagai tersangka oleh penyidik sampai pada proses persidangan.

Sebagaimana yang telah difirmankan oleh Allah SWT dalam Surat al-Najm ayat 38 yang artinya: "(yaitu) bahwasanya seorang yang berdosa tidak akan memikul dosa orang lain."

Menurut penulis, asas praduga tak bersalah yang kemudian diwujudkan dalam sistem pembebanan pembuktian kepada pihak penggugat atau Jaksa Penuntut Umum pada Hukum Acara Pidana Islam, merupakan bagian dari penegakan Hak Asasi Manusia. Islam memandang bahwa pada hakikatnya manusia dimata hukum adalah sama. Baik itu perlakuannya maupun status 
hukumnya. Menjadi tidak sama manakala statusnya berubah dari warga negara yang bebas menjadi warga negara yang didakwa melakukan perbuatan melawan hukum. Hak Asasi Manusia menjadi tolak ukur dalam penegakan hukum di Indonesia, setiap orang wajib menjunjung tinggi harkat dan martabat manusia, tegasnya pada aspek hukum, orang tidak boleh disangka bersalah sebelum hakim menyatakan ia bersalah.

Lebih lanjut sistem pembebanan terhadap Jaksa Penuntut Umum yang dibebani pembuktian untuk membuktikan apa yang didakwakannya merupakan bagian dari ketaatan kita kepada perintah Allah SWT dan Rasullullah. Allah berfirman dalam Surat an-Nisa ayat 59 yang artinya: "Hai orang-orang yang beriman, taatilah Allah dan taatilah Rasul (nya), dan ulil amri di antara kamu. Kemudian jika kamu berlainan pendapat tentang sesuatu, Maka kembalikanlah ia kepada Allah (Al Quran) dan Rasul (sunnahnya), jika kamu benar-benar beriman kepada Allah dan hari kemudian. yang demikian itu lebih utama (bagimu) dan lebih baik akibatnya".

Dalam hal tindak pidana korupsi atau ghulul atau risywah, merupakan bentuk jarimah yang korbanya bukan seorang perorang melainkan institusi negara. Korupsi merupakan masalah yang sangat serius, karena tindak pidana korupsi dapat membahayakan setabilitas, keamanan negara, pembangunan sosial dan ekonomi masyarakat, politik bahkan dapat pula merusak nilai-nilai demokrasi serta moralitas bangsa. Hal itu dapat terjadi karena dapat berdampak membudayanya tindak pidana korupsi tersebut.

Dimasukkannya sistem pembuktian terbalik pada tindak pidana korupsi, merupakan upaya pemerintah Indonesia dalam rangka mengembalikan kerugian keuangan negara yang ditimbulkan dari perbuatan korupsi. Alasannya adalah :

1. Berdasarkan data kerugian keuangan negara yang diuraikan pada bab pendahuluan subbab latar belakang masalah, sangatlah tepat bila Indonesia disebut korban kejahatan korupsi 
2. Dana atau asset yang dikorupsi tersebut adalah harta kekayaan negara Indonesia yang harus diperuntukkan bagi pembangunan dalam upaya meningkatkan kemakmuran dan kesejahteraan rakyat Indonesia. Kejahatan korupsi telah menghilangkan kesempatan rakyat Indonesia untuk menikmati hak-haknya dan menempatkan sebagian besar rakyat hidup dibawah garis kemiskinan

3. Negara memiliki kewajiban untuk melindungi dan menciptakan kesejahteraan bagi rakyatnya melalui pencapaian alternatif sumber pendanaan. Salah satu sumber pendanaan tersebut diambil dari upaya Negara dalam mengembalikan aset kejahatan korupsi

4. Upaya pengembalian aset memiliki makna preventif dan represif. Makna preventif yang terletak pada pengungkapan kepada publik bahwa tiada tempat yang aman bagi pelaku tindak pidana korupsi. Sedangkan makna represif terletak pada pemidanaan para pelaku tindak pidana korupsi

Dari aspek maqasid syariat, ketetapan hukum Islam berpijak pada pemeliharaan kemashlahatan manusia sampai akhir hayat. Karena itu Islam mengharamkan semua bentuk kemadharatan, kejahatan dan kerusakan serta melampaui batas yang ditetapkan. Kemaslahatan manusia menjadi syarat utama dalam istinbath hukum. Kaidah umum dalam hukum Islam telah menyebutkan :

$$
\text { جَلْبُ الْمَصَا لِحِ وَدَزْءُ الْمَفَا سِدِ }
$$

"Meraih kemaslahatan dan menolak kemafsadatan"

Demikian pula sebaliknya apabila menghadapi mafsadah dalam waktu yang sama, maka harus di dahulukan mafsadah yang paling buruk. Apabila berkumpul antara maslahat dan mafsadah, maka yang harus dipilih adalah yang maslahatnya lebih kuat, dan apabila sama kuatnya maka menolak mafsadah lebih utama dari meraih maslahat, karena menolak mafsadah itu sudah merupakan bagian dari maslahat.

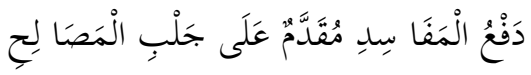


"Menolak mafsadah didahulukan daripada meraih maslahat"

Telah dikemukakan di atas bahwa tujuan umum syari'at Islam adalah untuk membawa kemaslahatan manusia dalam hidup dan kehidupannya serta melenyapkan, meniadakan dan menolak bahaya (mafsadah) yang akan menimpa mereka. Perbuatan korupsi termasuk perbuatan yang bersifat mafsadah terhadap harta benda, dan kemanusiaan. Termasuk didalamnya tentang istinbath hukuman bagi pelaku kejahatan korupsi harus didasarkan pada kemaslahatan yang berorientasi pada upaya pengembalian kerugian keuangan negara. Dan juga istinbath mengenai metode pembuktian dalam upaya memulihkan kerugian keuangn negara.

Dalam kaidah fighiyah telah dirumuskan :

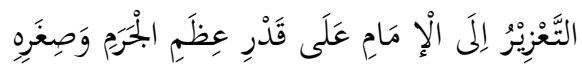

“Berat ringannya sanksi ta'zir diserahkan kepada imam (hakim) sesuai dengan besar kecilnya kejahatan yang dilakukan"

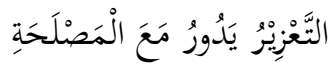

"Sanksi ta'zir bergantung pada kemaslahatan"

Kaitannya dengan sistem pembuktian terbalik pada tindak pidana korupsi, merupakan salah satu cara yang dianggap paling ampuh untuk mengembalikan kerugian keuangan negara akibat perbuatan korupsi. Disadari atau tidak disadari, bahwa tidak cukup hanya memidanakan pelaku kejahatan korupsi saja melainkan yang terpenting adalah bagaimana keuangan negara bisa pulih kembali.

Pada perkara krorupsi seperti yang dijelaskan sebelumnya, pembuktian terbalik hanya dapat diterapkan pada perbuatan suap menerima gratifikasi dan harta benda terdakwa yang didakwakan atau belum didakwakan. Jika ditinjau dari sudut pandang objek tersebut, sebenarnya pembuktian terbalik hanya diperuntukkan yang kaitannya dengan pemulihan kerugian negara. Dengan kata 
lain bukan pada subtansi perbuatan perkara pokok yang didakwakan kecuali menerima suap gratifikasi senbagaimana dimaksud pasal 12B UU Tindak Pidana Korupsi.

Menurut penulis, nampaknya dari pendekatan maqasid syariat ini, terjadi polarisasi pembebanan pembuktian yang semula hanya dibebankan pada pihak jaksa penuntut umum, dalam perkara korupsi ini dapat bergeser pada pembebanan pembuktian terhadap terdakwa demi kemaslahatan bangsa dan negara. Dengan kata lain kemaslahatan bangsa dalam memberantas kejahatan korupsi sekaligus upaya pemerintah memulihkan keuangan negara sangatlah bergantung pada diterapkannya metode pembuktian terbalik. Polarisasi mekanisme pembuktian ini sesungguhnya merupakan bagian dari menjalankan asas atau kaidah fighiyah :

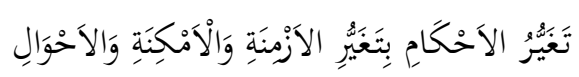

"Perubahan hukum menurut perubahan zaman, tempat dan keadaan"

Sebelum adanya sistem pembuktian terbalik Jaksa Penuntut Umum merasa kesulitan dalam hal membuktikan harta benda terdakwa yang diduga berasal dari perbuatan korupsi benar-benar hasil dari perbuatan korupsi, mengingat regulasi transaksi ekonomi kita tdak bisa mendeteksi sejauh mana sumber harta kekayaan seseorang. Namun paska di undangkannya UU No. 31 Tahun 1999 yang memuat ketentuan pembuktian terbalik, Jaksa Penuntut Umum merasa mudah dalam mengungkap perkara korupsi.

Kesulitan yang dihadapi jaksa penuntut umum ini, akan berakibat pada lemahnya bukti-bukti yang diajukannya dalam persidangan pada perkara pokok, sehingga potensi terdakwa dijatuhi pidana oleh majelis hakim baik itu pidana pokok maupun pidana tambahan yang berupa perampasan harta benda terdakwa adalah ringan,yang ada hanyalah terdakwa akan bebas bari segala tuntutan. 
Penulis berpendapat, jika ditinjau dari asas praduga tak bersalah, sistem pembuktian terbalik tersebut sebenarnya justru menguntungkan bagi terdakwa. Terdakwa bisa mempergunakan pembuktian terbalik terhadap harta kekayaannya yang diperoleh secara halal, dan apabila berhasil dalam upaya pembuktiannya, hasil tersebut dipergunakan sebagai bukti yang meringankan bagi terdakwa.

Dengan demikian pembuktian terbalik dalam perkara korupsi merupakan alternatif untuk mencapai kemaslahatan dalam rangka penegakan hukum terhadap kejahatan korupsi yang semakin meresahkan rakyat Indonesia dan untuk mencapai kemaslahatan dalam bidang perekonomian negara. Dengan pulihnya keuangan negara akibat perbuatan korupsi diharapkan pembangunan untuk mensejahterakan rakyat Indonesia yang sempat tersendat akibat dananya dikorupsi dapat dilanjutkan kembali, sehingga kemaslahatan rakyat Indonesia semakin terjamin. Sebagaimana fungsi adanya pemerintah terhadap rakyatnya.

\section{Penutup}

Pembuktian terbalik dalam mengembalikan kerugian keuangan negara pada tindak pidana korupsi adalah upaya pemerintah yang bersifat represif, preventif dan restoratif dalam kaitanya memulihkan kerugian keuangan negara akibat perbuatan korupsi. Sebagai bagian dari memulihkan keuangan negara, penuntut umum yang merupakan wakil negara dalam penegakan hukum, membebankan pembuktian harta benda terdakwa yang diduga berasal dari tindak pidana korupsi untuk membuktikan bahwa harta benda tersebut diperoleh dari cara yang halal. Jika kewajiban terdakwa sebagaimana amanat pasal 37 UU Tindak Pidana Korupsi ini tidak dipergunakan sebagaimana oleh terdakwa, maka hal ini akan mempermudah penuntut umum dalam membuktikan bahwa terdakwa melakukan tindak pidana korupsi sebagaimana dakwaannya, karena ketidak berhasilan 
terdakwa dalam membuktikan harta bendanya berasal dari cara yang halal akan menjadi tambahan alat bukti di persidangan.

Sedangkan dalam pandangan Hukum Acara Pidana Islam, pembuktian terbalik merupakan hal yang baru. Sepintas pembuktian terbalik bertentangan dari konsep dasar sistem pembuktian dalam Hukum Acara Pidana Islam, yaitu yang menekankan pendakwa atau penggugat yang harus membuktikan seutuhnya tentang gugatannya sebagaimana Sabda Nabi SAW. Namun hal tersebut dapat disimpangi dengan menggunakan pendekatan kemaslahatan yang merupakan tujuan dari ditetapkannya hukum. Kerugian keuangan negara yang timbul akibat perbuatan korupsi adalah salah satu faktor yang menghambat tersendatnya pembangunan nasional. Sehingga dengan menggunakan sistem pembuktian terbalik diharapkan kerugian keuangan negara dapat terpulihkan.

\section{Daftar Pustaka}

Alfitra. Hukum Pembuktian Dalam Beracara Pidana, Perdata Dan Korupsi Di Indonesia. Jakarta: Raih Asa Sukses, 2011.

Chaerudin, et all. Strategi Pencegahan dan Penegakan Hukum Tindak Pidana Korupsi. Bandung: Refika Aditama, 2008.

Chazawi, Adami. Hukum Pembuktian Tindak Pidana Korupsi UU No.

31 tahun 1999 yang diubah dengan UU No. 20 tahun 2001.

Malang: Bayumedia Publishing, 2011.

Departemen Agama RI. Al-Qur'an dan Terjemahannya. Bandung: Penerbit Diponegoro, 2001.

Djaja, Ermansjah. Memberantas Korupsi Bersama KPK (Komisi Pemberantasan Korupsi) KajianNormatif UU No. 31 tahun 1999 junto UU No. 20 tahun 2001 versi UU no 30 Tahun 2002. Jakarta: Sinar Grafika, 2008.

Gie, Kwik Kian. "Negara Terkorup di Asia”, dalam http://www. Kompas.com. diakses pada tanggal 31 Agustus 2012. 
Hamzah, Jur Andi. Hukum Acara Pidana Indonesia. Jakarta: Sinar Grafika, 2008.

- Perbandingan Pemberantasan Korupsi di Berbagai Negara. Jakarta: Sinar Grafika, 2005.

Indrayana, Denny. Negara Dalam Darurat Korupsi. Jakarta: Sinar Grafika, 2005.

Jauziyah (al-), Ibnu Qayyim. at-T\{uru | I q al-Hukmiyyat fi as-Siyasati as-Syar'yati. Terj. Adnan Qahar dan Anshoruddin. Hukum Acara Peradilan Islam. Yogyakarta: Pustaka Pelajar, 2006.

Kitab Undang-Undang Hukum Acara Pidana (KUHAP)

Mulyadi, Lilik. Asas Pembalikan Beban Pembuktian Terhadap Tindak Pidana Korupsi Dalam Sistem Hukum Pidana Indonesia Pasca Konvensi Perserikatan Bangsa-Bangsa Anti Korupsi 2003. Bandung: Alumni, 2007.

Prodjohamidjojo, Martiman. Penerapan Pembuktian Terbalik Dalam Delik Korupsi (UU No. 20 Tahun 2001). Bandung: Mandar Maju, 2009.

Putusan Mahkamah Agung RI No 664 K/ Pid/ 1986 tanggal 29 November 1990.

Sumaryanto, Djoko. Pembalikan Beban Pembuktian Tindak Pidana Korupsi Dalam Rangka Pengembalian Kerugian Keuangan Negara. Jakarta: Prestasi Pustaka Raya, 2009.

Undang-Undang Nomor 20 Tahun 2001 Tentang Perubahan Atas Undang-Undang Nomor 31 Tahun 1999 Tentang Pemberantasan Tindak Pidana Korupsi.

Undang-Undang Nomor 31 Tahun 1999 tentang Pemberantasan Tindak pidana Korupsi.

www. kpk.go.id diakses pada tanggal 4 September 2012 